\title{
Hirnantian (latest Ordovician) glaciations and their consequences for the Oslo Region, Norway, with a revised lithostratigraphy for the Langøyene Formation in the inner Oslofjorden area
}

\author{
Johan Fredrik Bockelie',, B. Gudveig Baarli² \& Markes Eric Johnson²
}

\author{
${ }^{1}$ Natural History Museum of Oslo, PO Box 1172, Blindern, NO-0318 Oslo, Norway. Present address: MOL Norge AS, Trelastgata 3, NO-0191 Oslo, Norway. \\ ${ }^{2}$ Department of Geosciences, Williams College, 947 Main Street, Williamstown, MA 01267, USA. \\ E-mail corresponding author (B. Gudveig Baarli):gbaarli@williams.edu
}

\begin{abstract}
During the Hirnantian Age (Late Ordovician) the Oslo Region was located in a subtropical setting with siliciclastic input and carbonate production. At that time the sea level fluctuated in the Oslo Region during three regressive-transgressive episodes, some of which involved subaerial exposure and coastal valley erosion. The last major sea-level drop resulted in the formation of a conspicuous network of incised valleys that were subsequently filled with sediment during the transgression in the latest part of the Hirnantian. The continuing transgressive event rapidly flooded the exposed land areas in the central Oslo-Asker district. The areas towards the west in mainland Asker and Sylling in the adjacent Modum district were first transgressed in the late Rhuddanian (Early Silurian). Primarily eustatic processes affected the area, but synsedimentary faulting may also have been in play. There are two distinct palaeovalley trends: one at Hovedøya in Oslo more or less NW-SE, with narrow valley sides, the other at Kalvøya and surrounding areas trending approximately NE-SW, with one valley more than $10 \mathrm{~km}$ long. There may have been more than one filling phase. Sediment fill of the last-formed incised valleys were mapped and correlated across a large area of the Oslo-Asker district. Four new members of the Langøyene Formation are proposed: the Skaueren, Høyerholmen, Pilodden and Kalvøya members. Strata of the lateral Langåra Formation began deposition during the Katian. The rest of the formation as well as the Skaueren and Høyerholmen members contain fossils belonging to the cold-water Kosov fauna of early to mid Hirnantian age. The Pilodden and fossiliferous parts of the Kalvøya members include a mix of cold-water Kosov and warm-water Edgewood faunas of late Hirnantian age. Detailed descriptions of many incised valley fill sections in Oslo and Asker are included to show the spectrum of the sediment fill composition.
\end{abstract}

Keywords: Ordovician-Silurian, glaciation, incised valley, stratigraphy, Norway

$\checkmark$ The senior author passed away October 7, 2016, the day after the manuscript to this paper was submitted for review. He acknowledged the manuscript and approved submittal. All new data in this paper are his contributions as is much of the text manuscript. The junior authors have edited and shortened Fredrik's manuscript and made illustrations from his meticulous pencil drawings. Their main contribution is to include bio- and chemostratigraphic data from available sources. This enabled correlations of the strata and additional conclusions.

Electronic Supplement: Lithostratigraphy

Received 6. October 2016 / Accepted 26. May 2017 / Published online 1. September 2017

\section{Introduction}

During the Hirnantian Age in the Late Ordovician
Period glaciations on the palaeocontinent of Gondwana affected sea level on a global basis. Recently there have been a multitude of articles documenting the numbers and effects of these glaciations in terms of

Bockelie, J.F., Baarli, B.G. \& Johnson, M.E. 2017: Hirnantian (latest Ordovician) glaciations and their consequences for the Oslo Region, Norway, with a revised lithostratigraphy for the Langøyene Formation in the inner Oslofjorden area. Norwegian Journal of Geology 97, 119-143.

https://dx.doi.org/10.17850/njg97-2-01. 
sea-level fluctuations on many continents at different palaeolatitudinal positions (Kaljo et al., 2001; Bergström et al., 2006; Brenchley et al., 2006; Štorch, 2006; Johnson \& Baarli, 2007; Davies et al., 2009; Ghienne et al., 2014; Demski et al., 2015; Kröger et al., 2015). The Oslo Region was situated in a subtropical position during the Ordovician (Torsvik \& Cocks, 2013), and the effects of sea-level changes are also recorded there.

Due to repeated glacial phases (Ghienne et al., 2014), one would expect a complex succession of regressive and transgressive system tracts during the Hirnantian, including subaerial exposures in certain areas. Kiær (1902) is the only worker to have suggested subaerial exposure in the study area while others have mentioned gradual shallowing into shore-face conditions during the Late Ordovician (Bruton et al., 2010).

The Cambro-Silurian sequence in the Oslo-Asker district is part of the frontal decollement unit of the Osen-Røa Nappe Complex (Nystuen, 1981; Bockelie \& Nystuen, 1985; Morley, 1986; Bruton et al., 2010) and, thus, allochthonous and influenced by folding and thrusting that occurred during the Caledonian orogeny. Even so, sufficient exposures exist to obtain an overall picture of Hirnantian geological history. The district appears to be the key for unlocking the local history of this time interval in the Oslo Region.

The purpose of this study is to update and document effects of both the glaciations and possible tectonic movements that resulted in very complex lateral and stratigraphic facies changes. Emphasis is on the last phase of erosion and transgression. The Hirnantian succession was earlier divided into two formations in the central Oslo Region. This study introduces a refined lithostratigraphic scheme in which four new members for the Langøyene Formation and a bed at the top of the Ordovician are added.

\section{History of Hirnantian research in the Oslo-Asker district}

Kjerulf (1857) divided marine deposits in the Oslo Region into 'Etage' 1 to 8, of which the upper Ordovician belonged to 'Etage' 5. He and Brøgger (1887) recognised calcareous sandstones as the uppermost part of the Ordovician succession in the Oslo area, particularly on the fjord islands in Oslo, Asker and Bærum. Kiær (1902) described in detail the uppermost Ordovician (Etage 5a and $5 b$ ) in Asker, both on some of the islands and on the mainland showing rapid changes in the strata, in what he defined as Etage 5b (most of Hirnantian). Kiær (1902) concluded that facies successions and changes indicating a shallowing of the deposits up to the base of the Silurian were related to the Taconic phase of the Caledonian deformation. Facies belts identified by him as parallel to the Caledonian deformation front were interpreted as original palaeo-bottom topographical features. He

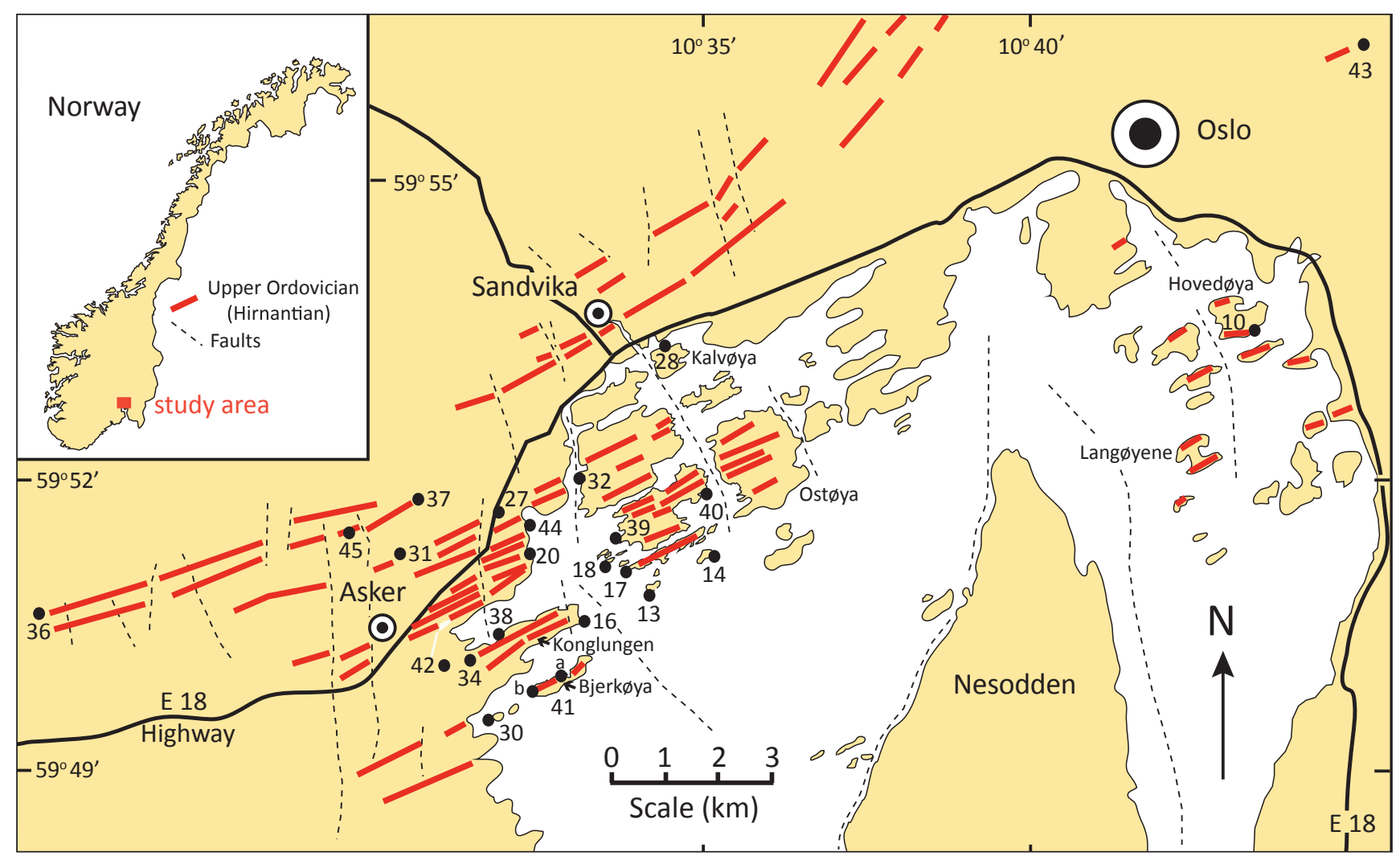

Figure 1. Map of Hirnantian strata in the Oslo-Asker district shown as red lines. Localities and numbers are those referred to in the text. 
recognised a range of facies belts from deeper-water brachiopod facies (Holorhyncus) to shallow-water beach deposits with conglomerates.

Spjeldnæs (1957) described a deep channel cutting through Upper Ordovician deposits on the island of Hovedøya in Oslo (Fig. 1). He suggested that it represented a tidal channel positioned across the Ordovician-Silurian boundary and established a new chronostratigraphic unit, which he called Etage 5c. Furthermore, Spjeldnæs (1957) regarded the Etage 5c beds to post-date a folding phase and suggested that the sediments within the channel were unconformable or disconformable on the underlying sediments.

Seilacher \& Meischner (1964), studying the Hovedøya outcrops and other sections, repeated Spjeldnæs' suggestions that the Etage $5 \mathrm{c}$ strata were erosional products deposited in longitudinal basins filled during successive phases. At Malmøya, they noted three phases of sediment fill. They also made a rough sketch of the channel at Hovedøya (without scale) and one sketch of a large (6 m long and more than $1 \mathrm{~m}$ wide) overturned block at Alnabru. It may have weighed more than 12 tons! The exposure at Alnabru has since been destroyed due to road building.

In his unpublished thesis, Lervik (1969) indicated that channels of similar age as those described by Spjeldnæs were common in Bærum. He considered them tidal in origin, formed during a general shallowing of the basin. He (Lervik, 1969, p. 91) pointed out that there is no clear angular unconformity between the Ordovician and the Silurian sedimentary rocks in Bærum west of Oslo.

Brenchley \& Newall (1975) defined new lihostratigraphic units in the Upper Ordovician of the Oslo-Asker district for an interval now interpreted to start in the upper Katian. These included the Husbergøya, Langåra and Langøyene formations. They accepted the channel at Hovedøya as a tidal channel, following Spjeldnæs, but they rejected Spjeldnæs' stratigraphic unit 'Etage 5c'. Brenchley \& Newall (1975) looked upon Stage 5a and $5 \mathrm{~b}$ as local chronostratigraphic stages with the boundary between them the basis of the Hirnantian Stage.

Stanistreet (1978) argued for future reinstalment of Spjeldnæs' concept of 'Etage' $5 \mathrm{c}$ as a chronostratigraphic unit. He correlated the 'channel' fill across into Asker and Bærum. His view on the 'tidal' channel at Hovedøya was that it related to a drop in sea level and subsequent transgressive fill during the later part of the Ordovician. $\mathrm{He}$ also documented that this event had regional significance.

Brenchley \& Newall (1980) suggested that the successions found in the Oslo Region reflect a record of glacioeustatic changes. They suggested a sea level lowering of about $150 \mathrm{~m}$ during the Katian-Hirnantian interval, but did not mention subaerial exposure except for the northern areas of the Oslo Region. They recognised a large number of exposures with channels and channel fill at different stratigraphic intervals and interpreted them as tidal in origin. They also documented a complex of facies relationships and inferred these to be related to basement faults controlling uplift.

Working in the Hadeland district to the north, Braithwaite et al. (1995) presented a model of both bioclastic and siliciclastic sediments brought in from the east during the Late Ordovician and Early Silurian. This was in contrast to Brenchley \& Newall (1975), who suggested input from either erosion off the nappes from the northwest or from the 'Telemark Land' to the west. Furthermore, Braithwaite et al. (1995) suggested that several faults were active during the Late Ordovician and into the Silurian. This is in agreement with Stanistreet (1983) regarding his Nesøya, Brønnøya and Bunnefjorden fault lines. They also suggested that the millet-seed quartz grains in Hadeland were derived from a mature landmass on the eastern side of the Oslo Region. They reported a lack of lithic grains, but the presence of some unweathered feldspars in eastern Hadeland that suggested a granitic igneous or metamorphic complex as source area. They also suggested that crystalline basement uplift may have been activated, which infers a Precambrian basement source of clastics for the Oslo Region. Working in the Oslo-Asker district, Tonstad (1983) observed no feldspars in the clastic rocks, only quartz at Høyerholmen. Braithwaite et al. (1995) rejected the interpretation of tidal channels set forth by Brenchley \& Newall (1975) and proposed their creation by catastrophic events. They argued against tidal channels, pointing out that there were no peritidal sediments amongst the lithoclasts within the channels, and there was little correlation between the channel fill and the surrounding sediment. They also found three superimposed channel systems on the island of Langøyene.

Brenchley et al. (1997) performed $\delta^{13} \mathrm{C}$ analyses to establish the age of the brachiopod Holorhynchus giganteus in the Oslo area and concluded that the brachiopod was of Katian age. This was supported by data from chitinozoa. They claimed there was a 'cryptic' unconformity between the Ordovician and Silurian strata. Therefore, they ascertained that Etage $5 b$ is largely missing in the northwest Asker area. Brenchley \& Marshall (1999) studied the sections at Hovedøya and Rambergøya looking to link extinction with isotope analyses. They claimed that the second phase of extinction happened during the mid-Hirnantian and that changes in $\delta^{13} \mathrm{C}$ values predate both the extinction and changes in sea level.

Kaljo et al. (2004) indicated a gap below the base of the Solvik Formation based on isotope studies. They found a less complete $\delta^{13} \mathrm{C}$ record at Kalvøya and Semsvannet 
than at Konglungø, all between channels, concluding that there was a difference in length of time with nondeposition between the three areas.

Testing chemostratigraphy in the Oslo Region, Bergström et al. (2006) accepted Brenchley \& Newall's stratigraphy (with the Hovedøya tidal channel). Based on the $\delta^{13} \mathrm{C}$ curve, they proposed that the upper parts of the Husbergøya Formation ought to be placed within the Hirnantian. The conodont Ozarkodina oldhamensis and the $\delta^{13} \mathrm{C}$ excursion in the oolites at the top of the Langøyene Formation in the section at Hovedøya suggested correlation to highstands as observed in the North American Leemon Formation of the midcontinent, the Saldus Formation in Estonia, and the Loka Formation in Sweden. All these formations were deposited in the upper part of Hirnantian (M. persculptus graptolite Biozone). Since these oolitic beds were cut by channels indicating a lowstand in sea level, they correlated the channel fill with the American midcontinent and the beginning of the postglacial melting in Gondwana during the latest part of Hirnantian. They also inferred a possible time gap between the Langøyene and Solvik formations.

Brenchley \& Cocks (1982) conducted extensive faunal studies on ecological associations confirming the presence of Hirnantian brachiopods and trilobites. Brenchley \& Cullen (1982) worked further on the bathymetrical position of the different Hirnantian associations. A few other taxonomic studies based on material from these rocks are published (Neuman, 1969, 1975 on corals; Bockelie, 1984 on echinoderms; Cocks, 1982 on brachiopods, among others).

\section{Methods}

Asymmetrical folding, thrusting and faulting of the Cambro-Silurian rocks in the Oslo Region due to Caledonian and subsequent Permian deformation make inter-regional interpretations challenging. Detailed geological mapping in Asker and Bærum, as well as parts of Oslo, on the scale of 1:5000 has proven necessary to obtain a sufficiently detailed picture of the tectonic deformation of the strata to form a basis for more detailed analysis. Compilations are published at a scale of 1:50,000 (Naterstad et al., 1990) and recently at a scale of 1:10,000 for a restricted area (Bockelie \& Rui, 2015). In order to study the details of the uppermost Katian and the Hirnantian, the 1:5000 maps may not be sufficiently detailed. In certain areas 1:2000 or 1:1000 maps have been used to follow the distribution of the KatianHirnantian formations and members.

Along strike, Upper Ordovician strata can generally be followed from one island to the next for several kilometres (Fig. 1). Detailed measured sections at every
$5 \mathrm{~m}$ along strike have been attempted wherever possible, and locally every $1 \mathrm{~m}$ was measured along strike. These measured sections (up to $300 \mathrm{~m}$ in length) were drawn as continuous profiles wherever possible. Measuring sections in such detail reveals facies successions within the different stratigraphic units as well as facies changes along strike. Thus, it has been possible to establish fairly accurate stratigraphic, structural and geographical relationships among the measured sections along strike in certain areas. Locality numbers have been standardised, using numbers from Brenchley \& Newall (1975) and subsequent additions by the present authors (Fig. 1).

At Hovedøya, the entire southern part was mapped at a scale of 1:1000 from its western tip towards the east over a distance of about 300-400 m. The actual incision was measured at a metre scale in order to build a continuous section.

By applying this level of detailed study to all the sections exposed along strike, it is possible to form a basis for correlations between strike sections. More than 20 strike sections have been mapped, many of which cannot be followed for more than 3-4 km. Kiær (1902) was the first to apply this type of analysis in order to define a series of facies maps. He suggested that to unfold the

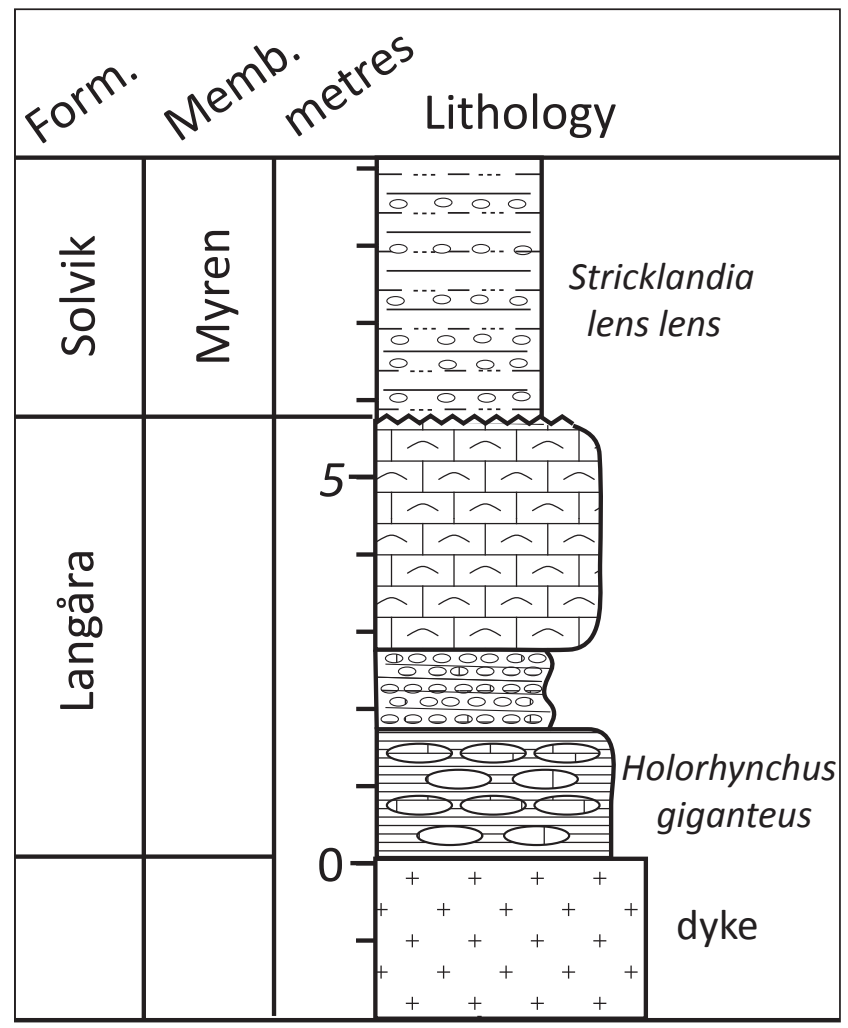

Figure 2. Lateral development of the Langara Formation at Olledalen, Asker (Loc. 36; Fig. 1). The brachiopod Holorhynchus giganteus is present in the nodular limestone of the lower parts that show a normal development for the formation. The thick, more homogeneous, limestone bed near the top is common only in the westernmost parts of the formation. 


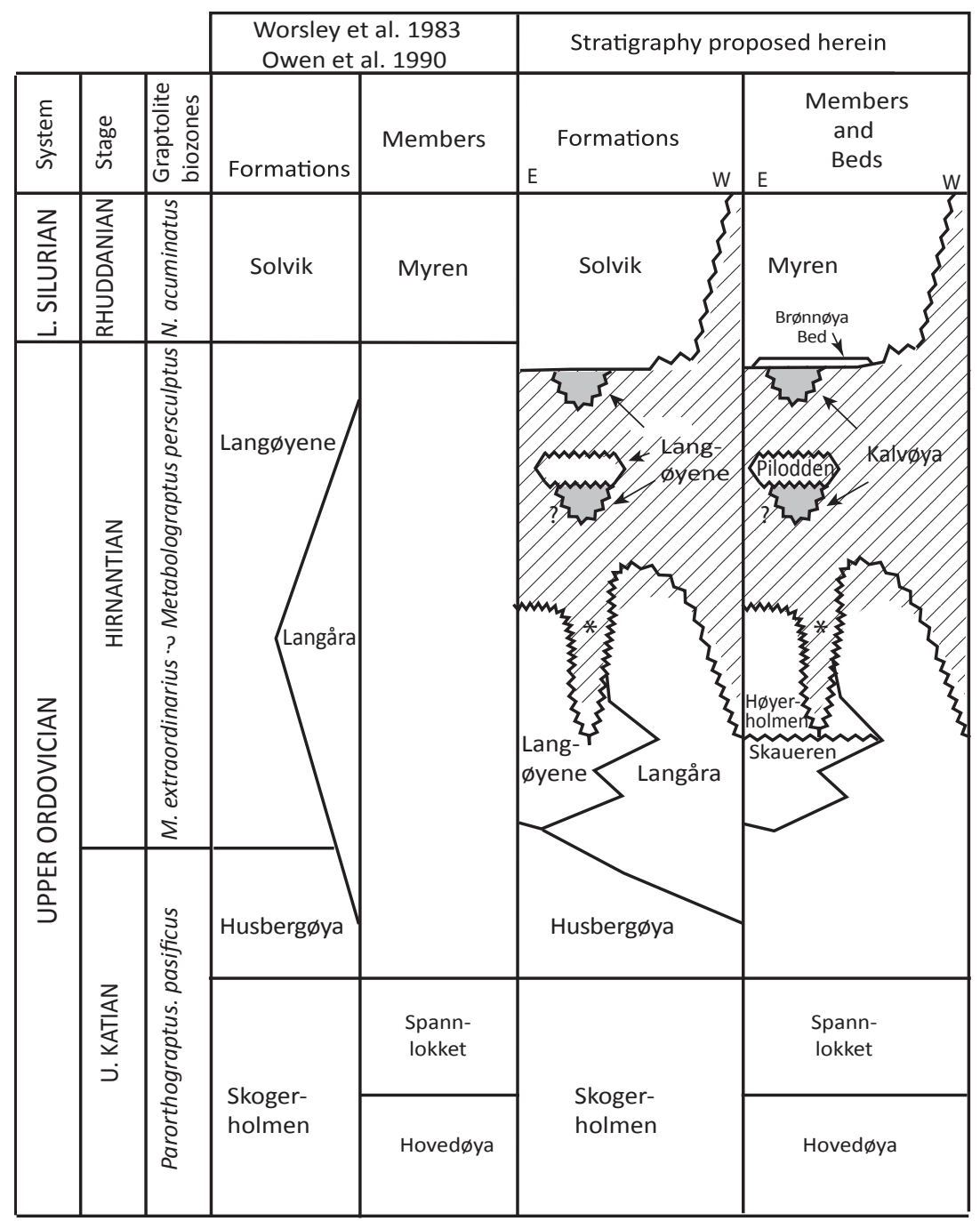

Figure 3. Schematic stratigraphic correlation chart across the region. On the left side are former divisions as lithostratigraphic units, while the right side shows correlations of formations and members in the present work. The exact stratigraphic duration of gaps is partly unknown and may fluctuate markedly across the area. There are many channel incisions (marked by ${ }^{*}$ ) and the degree of removed strata varies from just slightly cutting into the Høyerholmen Member of the Langøyene Formation (as shown) to much deeper cuts into the Mjøsa Member of the Skogerholmen Formation.

strike sections and relate them correctly, a stretching of some 2.5 times would give a reasonable estimate. Stanistreet (1978) used a $2 \mathrm{x}$ value for the stretching of his palinspastic reconstructions. This is probably on the lower side due to asymmetrical folding and also thrusting. In some areas there are appreciable amounts of overthrusting which is difficult to calculate. For the current reconstruction, the present authors employed a value of 2.5 times for the stretching.

\section{Results}

The current Upper Ordovician stratigraphic scheme for the Oslo-Asker district (Brenchley \& Newall, 1975, fig. 3, p. 245) is based on a relatively simple geological model founded on observations from the islands near Oslo and the outer islands in Bærum and Asker. For these areas, they showed that the uppermost Ordovician consists of silty shale (the Husbergøya Formation) succeeded on the outer islands by a sandstone unit (Langøyene Formation) that in its upper part is an oolitic limestone with millet-seed quartz grains. Towards Asker in the west, a calcareous shale (Langåra Formation) is lateral to parts of the two formations. The Solvik Formation overlies the Langøyene Formation as a synchronous deposit in their model (Brenchly \& Newall, 1975). However, this model is overly simplistic.

In some areas to the west (Konglungen), there are two separate and distinct sandy deposits within the Langåra Formation. These sandstones are wedges of the Langøyene Formation. Farther west (onshore in Asker), the Langøyene Formation is replaced by bioclastic limestones. These are generally considered as belonging to the Langåra Formation, but are not genetically connected. 
At Olledalen in Asker there is a section that traditionally has been described as the Langåra Formation (Fig. 2), but this section is dominated by calcareous sediments different from the more shale-rich sediments normally ascribed and seen farther east. At present, they are described as a lateral facies development of the Langåra Formation. Further investigation may warrant the erection of a separate stratigraphic unit.

The division of the former 'Etage' $5 \mathrm{a}$ and $5 \mathrm{~b}$ into three formations by Brenchley \& Newall (1975) is inadequate to describe the present understanding of the depositional history for the Upper Ordovician. Several successions with important breaks between them have been lumped together without recognising their complexity. Brenchley, himself, acknowledged this (Brenchley et al., 1997) and wrote that the stratigraphy that he and Newall had established in 1975 was in need of revision.

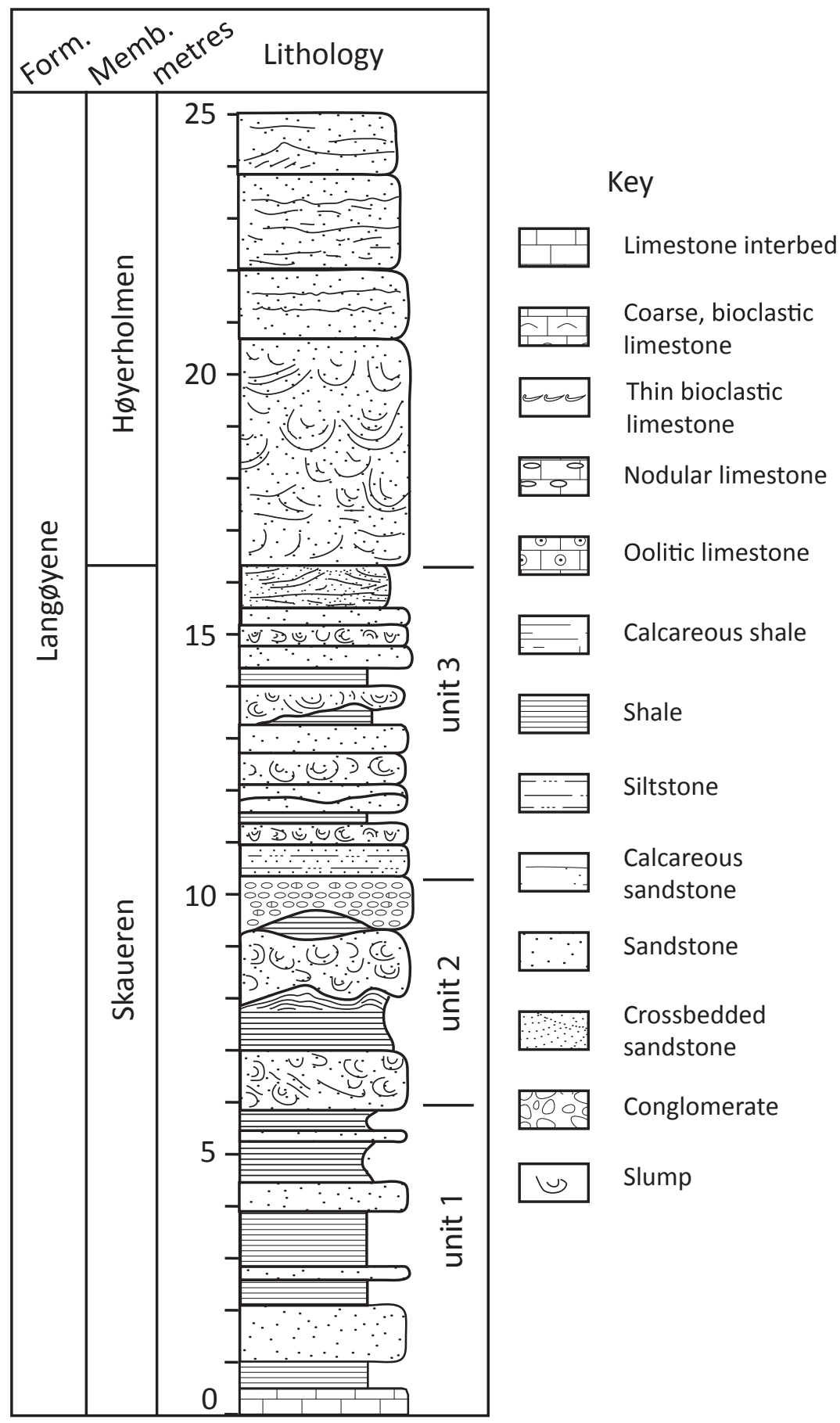

Figure 4. Skaueren Member and part of the overlying Høyerholmen Member at Skogerholmen West, Asker (Loc. 13; Fig. 1). The key provides sedimentary symbols used in all the following stratigraphic sections. 


\section{Stratigraphy}

Some necessary additions to the lithostratigraphic intervals are described in the Electronic Supplement. The principal evaluation is made from a section at Hovedøya comprising the transition from the Langøyene Formation into the base of the Solvik Formation. Studies from Asker and Bærum also are important elements, as described below.

The map in Fig. 1 shows the spatial distribution of the upper Katian and the Hirnantian in Oslo, Asker and Bærum. It differs somewhat from the distribution

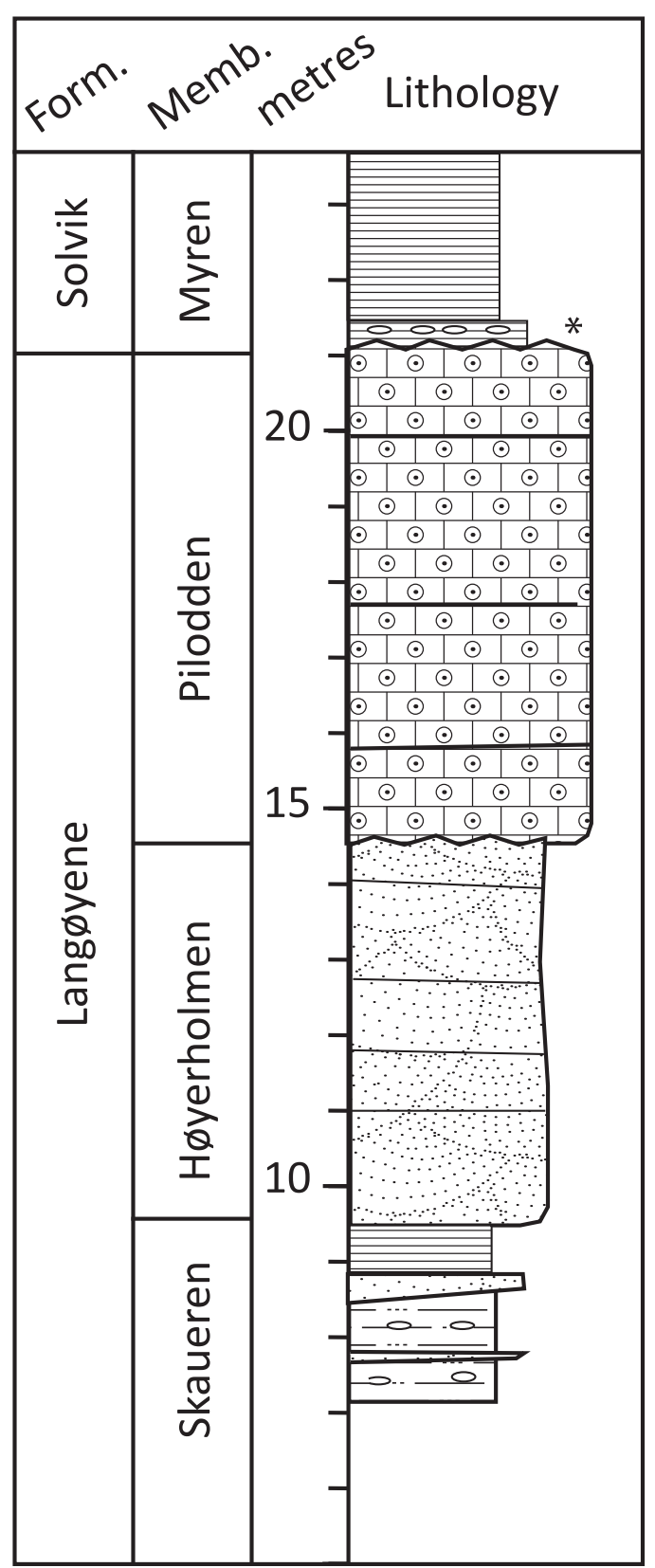

Figure 5. Section at the western end of Spannslokket, Asker (Loc. 18; Fig. 1), showing Skaueren, Høyerholmen and Pilodden members of the Langøyene Formation. The overlying Solvik Formation lies unconformably on the Pilodden member. Note: Asterisk $\left(^{*}\right)$ represents the Brønnøya Bed. shown by Brenchley \& Newall (1975, fig. 1). The revised lithostratigraphic scheme is given in Fig. 3 where the Langøyene Formation is divided into four new units to facilitate the descriptions and interpretations below. These units are in succeeding order the Skaueren, Høyerholmen and Pilodden members with type sections shown in Figs. 4 \& 5. The new Kalvøya Member contains strata of the incised valley fill (Fig. 6). A new bed, the Brønnøya Bed (Fig. 7), is defined at the base of the overlying Solvik Formation.

\section{Incised valleys in the Oslo-Asker district}

The Late Ordovician glaciations are well accepted and already Brenchley \& Newall (1980) acknowledged their influence in the Oslo Region, estimating a eustatic drop of about 150 metres. Similar trough-shaped surfaces as those found in the Oslo Region are also found in the Upper Ordovician in Iowa (Johnson \& Baarli, 2007). In those regions, such surfaces are interpreted as incised valleys. The trough-shaped erosion surfaces are found on

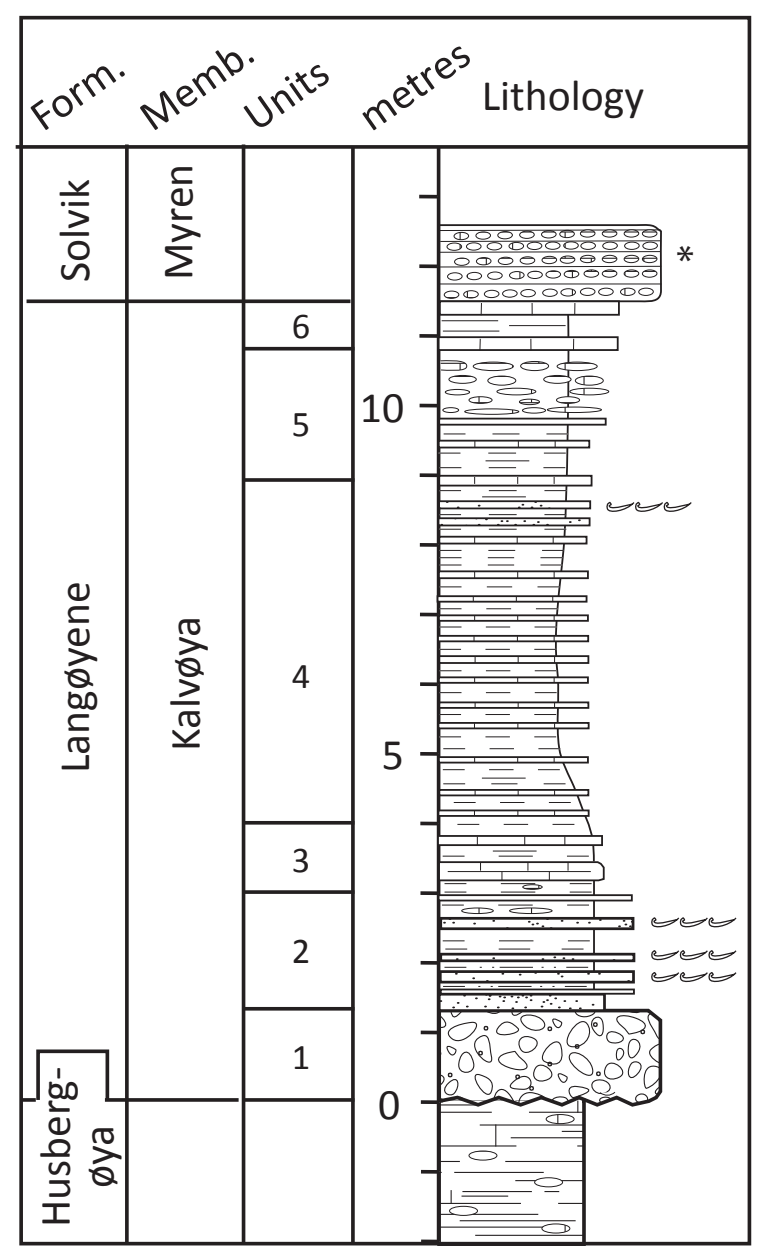

Figure 6. Kalvøya Member at Bikkjebukta, Kalvøya, the type section of the member, overlain by the Brønnøya Bed of the Solvik Formation. 


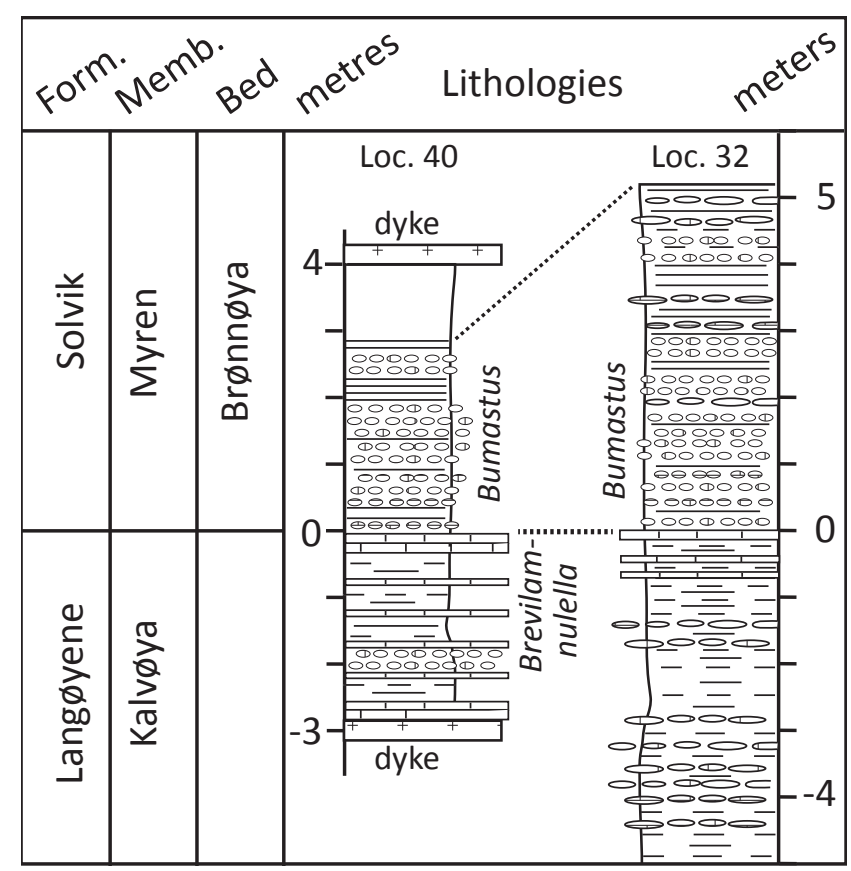

Figure 7. Correlation of strata from localites 32 and 40: Type section (left) of the Brønnøya Bed at Østre Brygge, Brønnøya (Loc. 40; Fig. 1), and an ancillary section (right) at Vestre Vei 55B, Nesøya. Note that the Brønnøya Bed is thicker here than in the type section.

Hovedøya, Kalvøya, western Nesøya, Holmen and many other areas in the Oslo-Asker district (the base of the Kalvøya Member of the Langøyene Formation; Fig. 3; Electronic Supplement). Brenchley and Newall described them as tidal channels in their various publications and the same interpretation is found in Stanistreet's papers. Stanistreet (1989) showed incisions in several figures and in the composition of the 'channel fill' and the 'final transgressive sequence', but explained the fill of the channels as due to storm events during the later part of the Hirnantian. Braithwaite et al. (1995, p. 211) argued convincingly against these being tidal channels. They commented on the presence of very large clasts, some of which were bored by Trypanites, indicating consolidation before transport, and suggested that the channels must have resulted from catastrophic events. A more logical explanation is that the epicontinental, relatively shallow and slightly sloping sea bottom across the central Oslo Region was drained as in Iowa where the conditions were similar prior to eustatic sea-level falls. The consequence of this exposure would be that erosion and incised valleys developed over larger areas, comparable to the sea-level drop and exposure on the New Jersey continental shelf during the Quaternary glaciation (Nordfjord et al., 2006). There, the shelf was exposed and eroded during maximum glaciation and the glacial valleys developed were subsequently drowned. If there were combined glacio-eustatic sea-level drops and active faulting in the Oslo Region, the palaeotopography would have been extremely variable. No deposits of nonmarine sediments are known in the Oslo-Asker district, but some areas (Rognskjær) show fossil mud cracks or desiccation cracks and may have been exposed to nonmarine conditions at times.

The largest blocks in the conglomerate incision fill at Hovedøya and at Alnabru in Oslo are $2.5 \mathrm{~m}$ across and more than $6 \mathrm{~m}$ long, respectively with sharp edges. No doubt such large blocks cannot have been transported very far. Scouring by storms or tidal currents only removes the finer sediment and probably not lithified strata of several cubic metres size, in some cases possibly tens of cubic metres. The most likely explanation is that these large blocks of strata were undercut and fell from the walls of incised valleys up to 15-20 m deep or more. Sand is common in the channels, particularly in the deeper parts where there is a general fining up sequence, whilst marine fossils appear slightly above the conglomerates.

Both Stanistreet (1983) and Braithwaite et al. (1995) presented various models for potential fault patterns through the Oslo Region during the Late Ordovician. The glacio-eustatic or combined tectonic and glacioeustatic events would lower the sea-level by several tens of metres. If an area were located in a shore-face setting, as is the case with the oolitic limestone of the Pilodden Member in the Langøyene Formation (Fig. 3), the result would be a palaeotopography in which the earlier seabed would lie 'high and dry' until the polar ice in the south melted and the sea transgressed over the OsloAsker district again. Meanwhile, there would have been considerable erosion and scouring of the landscape resulting in a complex of incised valleys caused by erosion by streams and rivers. How long such erosion lasted is not discernible at present, but it may conceivably have lasted for thousands or tens of thousands of years.

The locations and fill of the incised valley complex at selected localities are given below. Mapping has shown that some of the incised areas are connected. Lack of exposures and insufficient systematic searches made in certain areas limit a full understanding of the distribution of these valleys.

\section{The valley at Hovedøya}

The southern part of Hovedøya is the classical locality to demonstrate the latest Ordovician and transition into the Silurian (Kiær, 1908). The locality chosen by Brenchley \& Newall (1975) is important because it exposes the full Hirnantian succession preserved, both the normal one between channels and a section with an incised valley. These sections sit more or less on the same line of strike. Fig. 8 shows a section from east to west where the Pilodden Member of the Langøyene Formation rapidly disappears and is replaced farther west by a wellexposed valley incision. Bockelie (2013) described it as a palaeovalley, but provided no documentation. Below are more detailed measurements of the fill strata. 


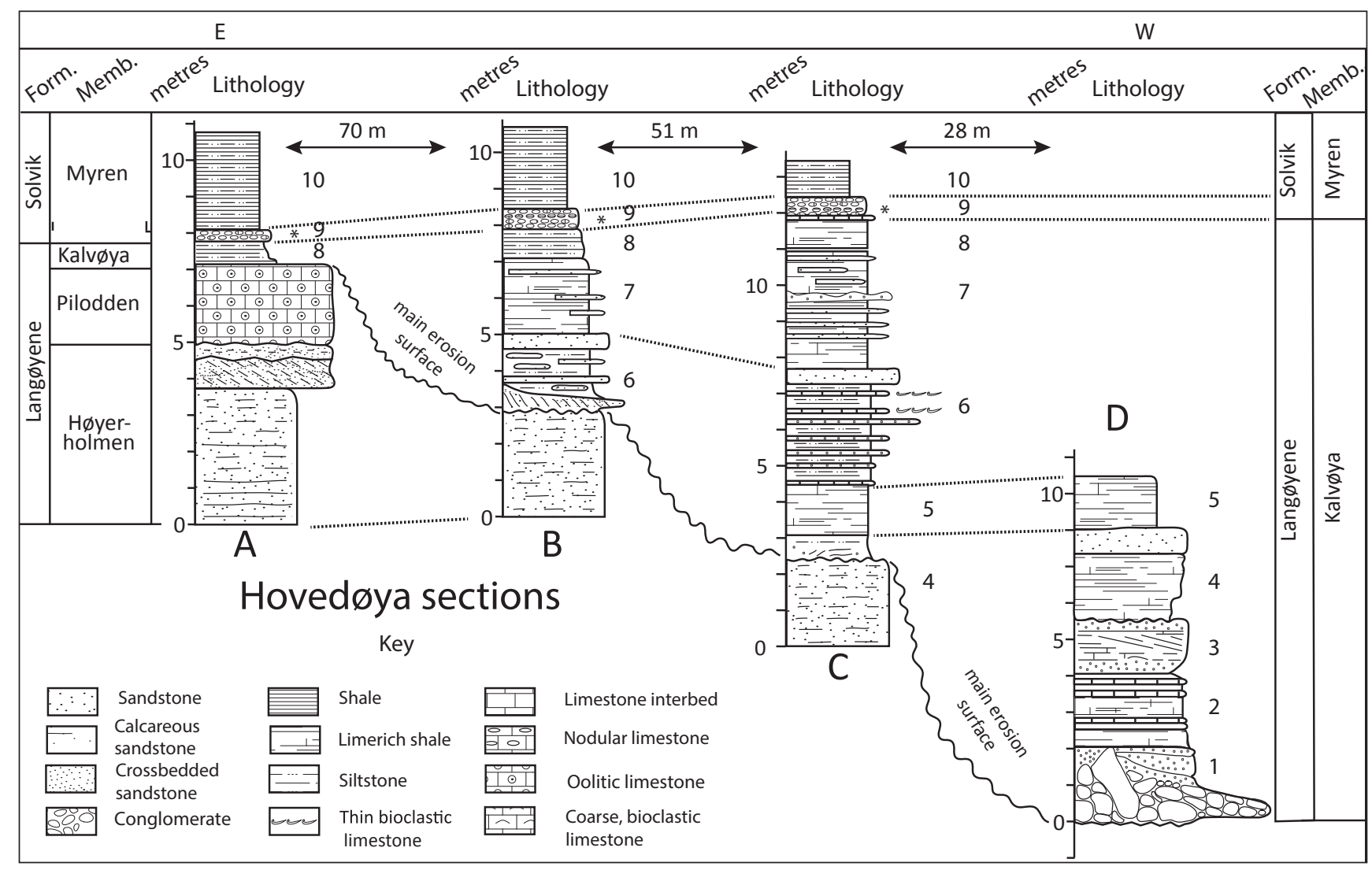

Figure 8. Measured sections (A to D) within the eastern flank of the palaeovalley of Hovedøya, SW (Loc. 10; Fig. 1). The valley is filled by 8 depositional units within the Kalvøya Formation. The Brønnøya Bed (marked by *) within the Myren Member of the Solvik Formation is unit 9, and unit 10 represents the rest of the Myren Member as exposed in these sections.

In order to better document this incision and to study the amount of erosion, the extent of the incision and its relationship to the fill and its lateral facies, the deepest point of the incision is used as the reference point, and measurements were recorded west and east of it (Fig. 9). From this deepest part of the incision, 56 metres were measured towards the west, and 79 metres to the east up to the fault with a dyke, which forms a pronounced feature in the terrain (Fig. 9).

The incision can be seen to cut down more than $10 \mathrm{~m}$ in the deepest part. Detailed mapping reveals that it is terraced, and at least two terrace levels can be identified, $11 \mathrm{~m}$ to the east and $34 \mathrm{~m}$ to the east, as well as $20 \mathrm{~m}$ and $40 \mathrm{~m}$ to the west of the deepest part of the incision (Fig. 9). This shape is typical of an incised valley with periods of stand-still during the transgressive systems tract. The nature of the fill reveals a practically N-Strending palaeovalley through which the sea entered during the transgressive system tract in the later part of the Hirnantian.

The incised valley can be followed until it reaches a NNW-SSE-trending Permian (?) fault containing a dyke $79 \mathrm{~m}$ east of its reference point. Following the strata farther east, considerable complexities can be demonstrated, most likely due to an overturned fold structure and the presence of a strike-slip fault in the upper part of the succession, which rapidly changes its angle and cuts below the valley fill. Detailed geological mapping has revealed that the massive limestone farther to the east is faulted against the shale of the Solvik Formation. The fault trace may cut into the uppermost part of the incised valley. This is more or less in the same area as where the thick-bedded limestones of the Pilodden Member increase in thickness to about 4-5 m. It is possible that the southwestern edge of the Pilodden Member formed an escarpment that may have been deformed during the Caledonian orogeny in this area, due to differences in competence resulting in both the overturning of the strata as well as some transpressional movements along the fold axis at the edge of the incised valley. The fault is mapped well below the palaeovalley fill and ends at the top of the Husbergøya Formation on the southwestern side of the island.

The different strata along the cross-section of the palaeovalley are given unit numbers, characterising smaller intervals of the fill that can be traced from crosssections A through D (Figs. 8 \& 9A, B). Unit 1 is the deepest sediment package found in the incised valley, whereas the shales of the Solvik Formation above the Brønnøya Bed define the completed drowning of the palaeovalley. 

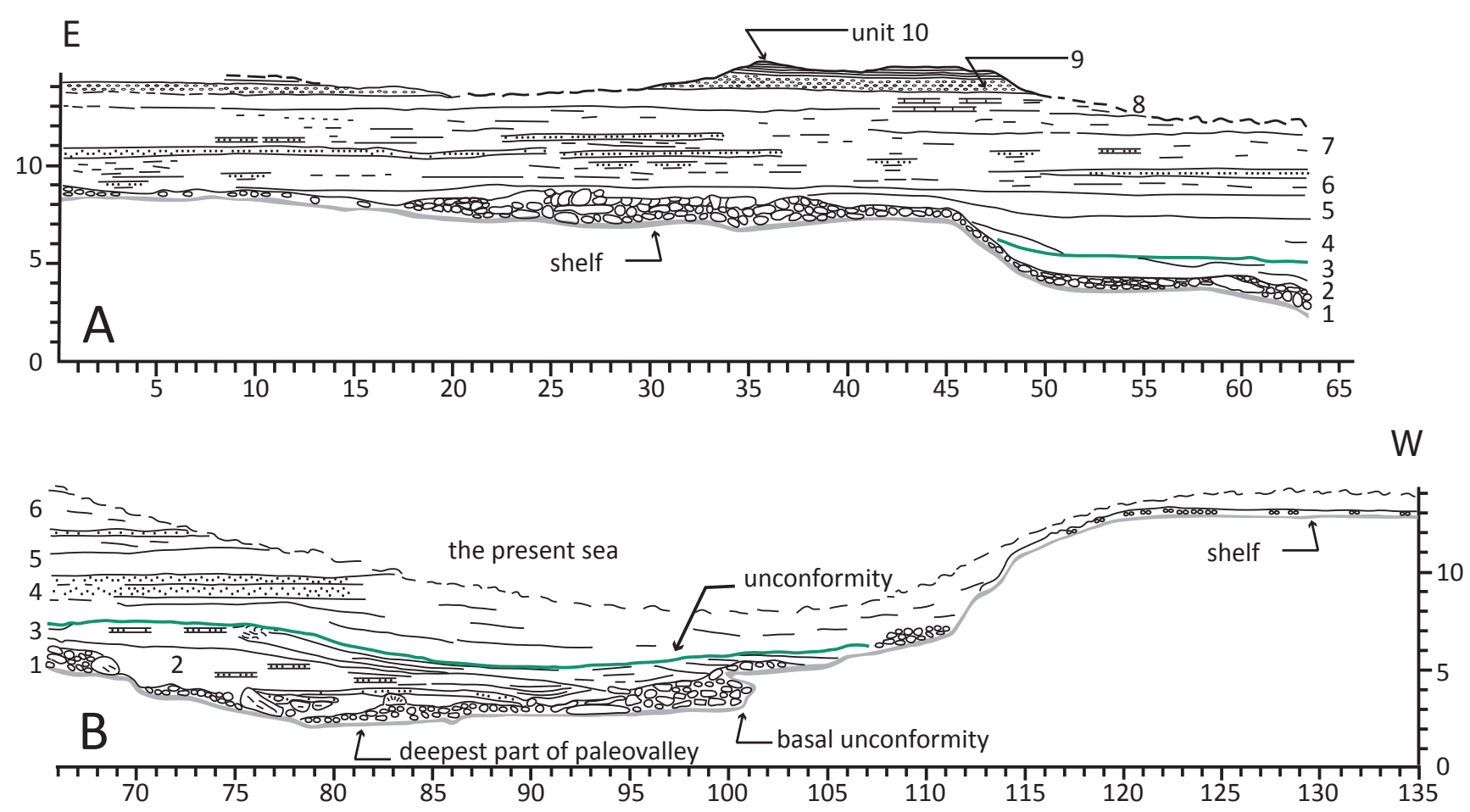

Figure 9. Profile across the palaeovalley at Hovedøya SW. Profile (A) shows the eastern half of the channel cut that continues below (profile B) moving towards the west. Vertical and horizontal scales are the same. Note that the palaeovalley profile is more or less symmetrical around the deepest part of the valley with a rapid increase in slope at a distance of $34 \mathrm{~m}$ on both sides. The western part dips into the sea (dashed line denotes the beach). Note the variation in thickness of the conglomerate and the size of the largest blocks in the deepest part of the palaeovalley.

Unit 1. The basal fill of the incised valley generally consists of a conglomerate with blocks of variable sizes eroded from the Pilodden and Høyerholmen members of the Langøyene Formation. These conglomerate blocks were not deposited all at the same time. Detailed studies of the relationship of the conglomerates to the overlying sediments indicate that the conglomerates were filled in by undercutting of overhangs, or as storm-generated fill deposits that tumbled down slope. The conglomerate blocks are in places imbricated, but also missing in some areas, thus recording a complex and long-term story as the palaeovalley was filled in.

In the deepest part of the valley, erosion reached to a depth of about $16.4 \mathrm{~m}$ below the top of the Brønnøya Bed (nodular limestone unit 9) of the Solvik Formation. Conglomeratic blocks are large (up to one cubic metre or more) and the conglomeratic horizon with variable thickness lines the palaeovalley (Figs. $8 \& 9 \mathrm{~A}, \mathrm{~B}$ ). About $5 \mathrm{~m}$ to the east of the deepest part (section D; Fig. 8), a large block is present; it is sharp-sided and shows no sign of long transport. Most likely it has fallen in as the cliff was undercut during the process of valley incision. The cliff gradually diminished due to erosion and its height became lower as the valley was filled in by sediment. Coarse millet-seed sand, presumably eroded from the Pilodden Member, is redeposited as matrix within the conglomeratic unit and close to the palaeoshore. This may be the reason why Brenchley \& Newall (1975) regarded the fill as tidal deposits, believing the coarse sand was time-equivalent to the upper part of the Høyerholmen Member (Fig. 3).

At about $20 \mathrm{~m}$ west of the deepest part, there is a 2 $\mathrm{m}$-high overhang with stacked conglomerate. It cannot be established whether or not the conglomerate was river transported and subsequently reworked by the marine transgression.

In the easternmost part (79 $\mathrm{m}$ east of the deepest part of the valley), the conglomerate $(60 \mathrm{~cm}$ thick) shows imbricated pebbles dipping SW into the palaeovalley. The pebbles consist of eroded Høyerholmen Member sandy limestone and large, weathered, redeposited quartz grains may occur as matrix. The imbricated pebbles may be very close to the line of the palaeoshore. The conglomeratic horizon thins to $30 \mathrm{~cm}$ over a distance of $4 \mathrm{~m}$ towards the west. The conglomerate shows variation in composition and thickness along strike. In the interval between 36 and $60 \mathrm{~m}$ east of the reference point (deepest part of incised valley), the conglomerate may be almost $1.8 \mathrm{~m}$ thick, whereas in a few places it was not deposited due to the presence of overhangs or the steep palaeovalley sides.

The topography was gradually levelled by a silty and sandy sediment that was deposited around the conglomerate and in several cases seems to be draping around and over the large conglomeratic blocks (Fig. 9). Therefore, this unit is only present in the deepest part of the valley. The sediments are brown, mostly silty and 
sandy with a somewhat irregular-bedded configuration, indicating rapid sedimentation. Millet-seed sands eroded from the Pilodden Member are present as distinct rapidly deposited beds. The sand is derived from the east side of the palaeovalley. Fossils are scarce, but a brachiopod was detected about mid-way in unit 1 . It may have been reworked. Consequently, it is unclear if these deposits are marine or nonmarine. Unit 1 can be studied along a distance of $15 \mathrm{~m}$ across the valley (section D; Figs. 8 \& 9).

Unit 2 extends $18-20 \mathrm{~m}$ to the east and about $14 \mathrm{~m}$ to the west. It reaches a maximum of $3 \mathrm{~m}$ in thickness and thins both to the east and to the west. It consists of laminated, fine to medium sand interbedded with calcareous sandstone beds containing large quartz grains reworked from the Langøyene Formation. Fossil brachiopods are commonly found in the lime-rich beds. Sediments show derivation from the east side of the palaeovalley. Synsedimentary faulting can be seen about $10 \mathrm{~m}$ west of the deepest part of the valley.

Unit 3 varies in thickness (maximum $1.5 \mathrm{~m}$ thick). It extends $26.5 \mathrm{~m}$ to the west and $32 \mathrm{~m}$ to the east reaching the valley walls (a later conglomerate cut into the unit in the west). At its base is a brown siltstone with scattered millimetre-size quartz grains. Some small brachiopods are present within thin limestone beds in its lower part. The uppermost part of unit 3 consists of interbedded quartz sandstone and calcareous sandstone (usually grey in colour), in contrast to the brownish colour of quartz-rich sediments. The upper part of the unit shows cross-bedding with directions from both sides of the palaeovalley towards the valley centre. No clear axial direction of transport has been observed. The top of unit 3 shows distinct evidence of erosion (Fig. 8).

Unit 4 continues to about $41 \mathrm{~m}$ east of the deepest part of the palaeovalley. It seems to continue all the way towards the west, dipping into the sea. It may be $6 \mathrm{~m}$ or more in thickness about $10 \mathrm{~m}$ west of the deepest centre of erosion. The trough-shaped erosion surface can be traced over a distance of $15 \mathrm{~m}$ within the valley. The base of the unit consists of a $20 \mathrm{~cm}$-thick bed with small slumps, possibly seismically triggered. The succeeding sediment generally consists of a medium sandstone interbedded with thin light-grey calcarenites, thickening towards the deepest part. A few escape burrows occur in the lower part of the unit. About $1.2 \mathrm{~m}$ above the base of unit 4 there is a laminated fine-sand interval with large brachiopods. This interval is succeeded by $8-10 \mathrm{~cm}$ of thick calcareous sandstone, with large 1-2 mm quartz grains. The base is sharp, and the sandy bed is a stormsand directed axially in the palaeovalley. Some $10-20 \mathrm{~cm}$ higher up is a $20-30 \mathrm{~cm}$-thick laminated fine-to-medium sand bed. This is succeeded by a $70 \mathrm{~cm}$-thick sand bed. Towards the east, almost where it dies out, there are finergrained, $0.5 \mathrm{~m}$-thick bioclastic beds in a shaly matrix that contain a Solenopora-like algae, small rugose corals and various brachiopods.

Unit 5 is a greyish-green silty shale or mudstone, partly calcareous, showing a dramatic decrease in grain size from unit 4 to unit 5 . It is about $1.5 \mathrm{~m}$ thick in the deepest exposed part and can be traced as an onlap event towards the east where it reaches as far as $70 \mathrm{~m}$ west of the deepest part of the valley. It is a good marker bed. In the more easterly part it fills in crevices in the conglomeratic boulders and can be very fossiliferous, containing a varied fauna of smaller fossils (ostracods? and other arthropods). Brachiopods and rugose corals are more common in the upper part.

Unit 6 is present only in the eastern part of the palaeovalley. The lithology changes quickly along its 70 metres of continuous exposure (Fig. 8). At its base is a 6 $\mathrm{cm}$-thick bioclastic bed, succeeded upwards by $80 \mathrm{~cm}$ of interbedded dark siltstone with starved ripples, in which Chrondrites burrows increase in density and frequency eastwards. The interval contains common Hindella and rhynchonellid brachiopods and rugose corals. Above this is a $12 \mathrm{~cm}$-thick storm sand with sharp base and rippled top followed by two $5 \mathrm{~cm}$-thick, fine-sandstone beds with a thin shale layer in between. A few, very thin, sandstone beds occur with coarse sand, probably reworked from the Langøyene Formation. They are not extensive and terminate before they reach much farther west into the deeper part. However, a distinct storm sand continues into the deeper part of the valley deposits where it may be $25-30 \mathrm{~cm}$ thick. Above this sandy unit follows an interbedded dark siltstone with starved ripples and frequent Chondrites burrows. Sporadic Heliocrinites occur in this interval and gastropods may be locally quite common as are small stick bryozoa (Hallopora sp.?). Above this occurs a one-metre interval with storm sands, each 1-6 cm thick, with very nicely weathered Chondrites and many other trace fossils. The uppermost part of unit 6 contains several bioclastic beds with rugose corals, crinoid ossicles, brachiopods, bryozoa and Cornulites.

In the easternmost part $(79 \mathrm{~m}$ east of the deepest part of the valley), unit 6 lies directly on the conglomerate. Here (section B; Fig. 8), a $40 \mathrm{~cm}$-thick bioclastic unit with variable thickness gradually grades into or downlaps westward onto the greenish-grey calcareous shale (upper part of unit 5) after about 8-9 m (Figs. 8 \& 9). Bioclastic fragments comprise brachiopods, crinoid ossicles, bryozoa, rugose corals, trilobite fragments and possibly ostracods. Unit 6 is capped by a $40 \mathrm{~cm}$-thick storm sand of mostly bioclastic material that is very distinctive from about 40 to $79 \mathrm{~m}$ east of the deepest point in the palaeovalley.

Unit 7 is about $3.5 \mathrm{~m}$ thick, starting with a fine silty mudstone about $75 \mathrm{~cm}$ thick, succeeded by interbeds of storm sands and fine silty mudstones. A small Heliocrinites cystoid $(1.5 \mathrm{~cm}$ diameter $)$ occurs in 
the lower part of this unit. Within the unit, there are common rugose corals, gastropods, crinoids ossicles and brachiopods. Chondrites is present locally in clusters forming burrows about $10 \mathrm{~cm}$ in diameter. In the eastern part of the profile (section B; Fig. 8), Unit 7 is approximately $2 \mathrm{~m}$ thick as a calcareous mudstone with some interbedded storm sands and some rippledrift lamination. Thin clasts of coarse sand beds eroded from the lower parts of the Langøyene Formation are redeposited at various horizons within this unit. The amount of sand decreases gradually westwards into the deeper part of the drowned valley after $30-35 \mathrm{~m}$, but some of the sand beds can be traced laterally for more than $35 \mathrm{~m}$. Unit 7 is highly fossiliferous and contains calymenid trilobites, rugose corals, stick bryozoa, crinoid ossicles and small brachiopods (Hindella cassidea, Thebesia scopulosa) and frequent trace fossils (Chondrites, Diplocraterion), particularly in the upper 2 $\mathrm{m}$ of the unit.

Unit 8 amounts to $60-80 \mathrm{~cm}$, increasing in thickness westwards. It consists of a brown, weathered siltstone (dolomitic?) with 2-3 discontinuous limestone beds each approximately $10 \mathrm{~cm}$ thick. In the deeper part of the incised valley there appears to be a slightly higher frequency of nodular limestone layers within this unit, thus making the boundary between units 8 and 9 less sharp in that direction. Locally, this unit contains brachiopods. It also is a very good marker horizon found throughout the Oslo-Asker district.

Unit 9 consists of the Brønnøya Bed. The nodules are frequently somewhat irregular and 15-20 limestone beds occur within the $65 \mathrm{~cm}$ unit. On the transgressed surfaces away from the main incised valley, this limestone is thin and usually poorly fossiliferous. It increases to a $65 \mathrm{~cm}$-thick nodular limestone about $150 \mathrm{~m}$ east of the incised valley. The Brønnøya Bed contains fragments of Eospirigerina and other brachiopods, illaenid trilobites (Brenchley \& Cocks, 1982) and some bryozoan and orthocones.

\section{Interpretation of valley fill}

Rivers may have been responsible for transport of reworked blocks of Langøyene Formation and older sediments in the palaeovalleys. Some pebbles and boulders found in the conglomerate may have been undercut from valley sides and fallen in without much transport. The larger, angular blocks are always in the deepest parts of the valleys, and may be located where they fell. In some of the river-cut valleys, pebbles may have been transported more than $4-5 \mathrm{~km}$ down the palaeovalleys.

During the succeeding late Hirnantian, the river deposits may have been reworked by marine onlap. Shaly intervals in valley sides may not have been consolidated and could easily be washed out by the rising sea. The lithified limestones are thus undercut, and could easily break up and fall into the incised valleys where they are found today. This is typical for the section on the island at the outlet of Neselven in Asker (Loc. 27; Figs. 1 \& 10) where the mudstone between individual Palaeoporella limestone beds was washed out and the limestone layers were undercut and slid into the palaeovalley during the transgression. Most likely, this is also the case for the large blocks at Hovedøya and Alnabru, but they also could have been undercut by rivers.

Conglomeratic blocks of the Pilodden Member in the Langøyene Formation occur at the base of the incised valley and line the palaeovalley wall at different stratigraphic levels through the filling phases. Consequently, the conglomerate is a lateral facies to each of the units of the filling described below.

To the east in the uppermost parts, imbricated pebbles dip into the valley and indicate a position very close to a palaeoshoreline present during the later stages of the valley fill. The top of unit 3 shows distinct evidence of erosion (Fig. 8). This could be due to a lowering of the sea level. The same pattern of erosion may occur at Holmen in Asker (see description below). The incised valley, therefore, appears to have been filled in two phases. In a recent thesis, Sandbakken (2014) suggests a nonmarine lower fill of the incised valley. If so, that would be only unit 1 . Alternatively, units 2 and 3 were deposited close to the marine environment in order to explain the presence of brachiopods there, unless they are reworked.

The fill in the upper units (4-8 m thick) seems to be axial in orientation and transported from the south towards the north. The more massive limestone of the Pilodden Member was exposed above sea level and eroded. At the edges of the mapped incised valley, this exposed limestone was eroded during the transgression and shed a $4.5 \mathrm{~m}$-thick succession of rubbly limestones interbedded with thin storm sands towards the end of the filling history of the Hovedøya incised valley. The rubbly limestone (unit 6) may be a beach deposit and is generally $30-60 \mathrm{~cm}$ thick and laid down in what may have been a moderate-energy shore-face setting. Entering the incised valley, the amount of limestone pebbles is reduced and their size decreases, grading into more siltstone and silty mudstones as part of a slightly deeper-water fill. They are succeeded in Unit 7 by storm sand deposits.

The brown siltstone of Unit 8 represents an onlap event onto what was land during deposition of units 1-7. Consequently, the sediment may contain dolomite eroded from an onshore location. Oolitic blocks of the Pilodden Member are found throughout the fill from the base, so the incision must correlate with the latest part of the maximum HICE towards the end of Hirnantian. 


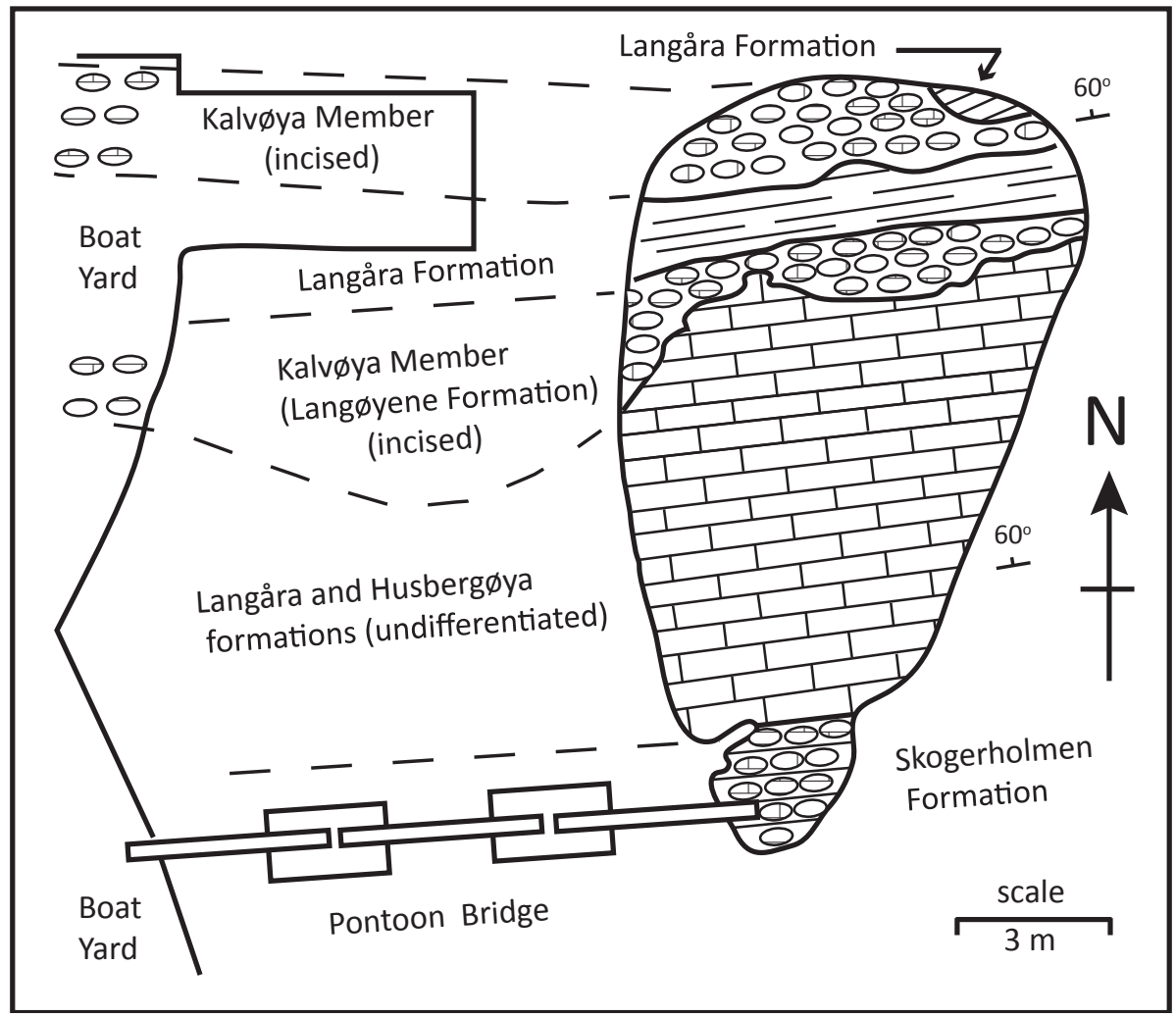

Figure 10. Island at the outlet of Neselven at Holmen (Loc. 27; Fig. 1), Asker, showing the distribution of different formations in a steeply tilted section. Note the two levels of channel sediments (Kalvøya Member of the Langøyene Formation) cutting into the Langåra and Husbergøya formations.

The asymmetrical profile of the whole palaeovalley on Hovedøya becomes obvious when the complete crosssection is shown (Fig. 9). Because the conglomerate is quite thin through the last $15 \mathrm{~m}$ of the profile and the projected top of the Pilodden Member is only 2.5 $\mathrm{m}$ higher than the conglomerate towards the west, the top of the Pilodden Member would have been close by. It is unknown if there was a continuous slope up to the limestone or if there was a sharp incision with a bank. However, the section ends at the sea next to an important $\mathrm{N}-\mathrm{S}$ trending fault.

\section{The incised valley at Kalvøya}

\section{(Sandvika; Loc. 28; Figs. 1 \& 6)}

A detailed description of the Kalvøya Member from the type section at Kalvøya is given under the definition of the formation (see Electronic Supplement; Fig. 6). Whereas the incised valley on Hovedøya SW is relatively narrow (about $150 \mathrm{~m}$ ) and approximately $14 \mathrm{~m}$ deep, the valley exposed at Kalvøya is about $350 \mathrm{~m}$ wide and about $18.5 \mathrm{~m}$ deep (Fig. 11). The valley at Kalvøya appears to connect to that on Holmen in a complex pattern. If this is the case, the valley in this area is more than $4 \mathrm{~km}$ wide. The gradient at Kalvøya is about $80 \mathrm{~cm}$ over a distance of $100 \mathrm{~m}$ in the eastern side of the valley axis, whereas at Hovedøya it is about $14 \mathrm{~m}$ over a distance of $100 \mathrm{~m}$.
Road section at E18, Vakås

(Asker; Loc. 31 ; Figs. 1 \& 12)

The section is located on the northwestern side of Highway E18 at Vakås, just below Nye Vakåsvei. The present description is preliminary and based on the photomosaic shown in Fig. 12. The total valley fill at this locality is $21 \mathrm{~m}$ thick from the base of the conglomerate to the base of the Solvik Formation at road level. The units described refer to this section and should not be correlated directly with those of Hovedøya. The section comprises a 8-10 m-high exposure showing rapid facies changes along strike.

Unit 1 is the base of the Kalvøya Member of the Langøyene Formation, a poorly sorted conglomerate with limestone pebbles from the underlying Palaeoporella beds. The conglomerate varies in thickness from 60 to $90 \mathrm{~cm}$ and cuts down into the Palaeoporella beds of the Langåra Formation, a nodular shale unit (see the right side of Fig. 12). The incision is deeper towards the road (SE) where it may cut about 1.5-2 $\mathrm{m}$ deeper than in the upper part of the section.

Unit 2 is approximately $2 \mathrm{~m}$ of dark shale with nodules of variable size and some sandy beds in the lowermost part. The lower, silty and sandy part containing corals onlaps the conglomerate. The top of the unit comprises interbedded shale, nodular limestone layers and thin 


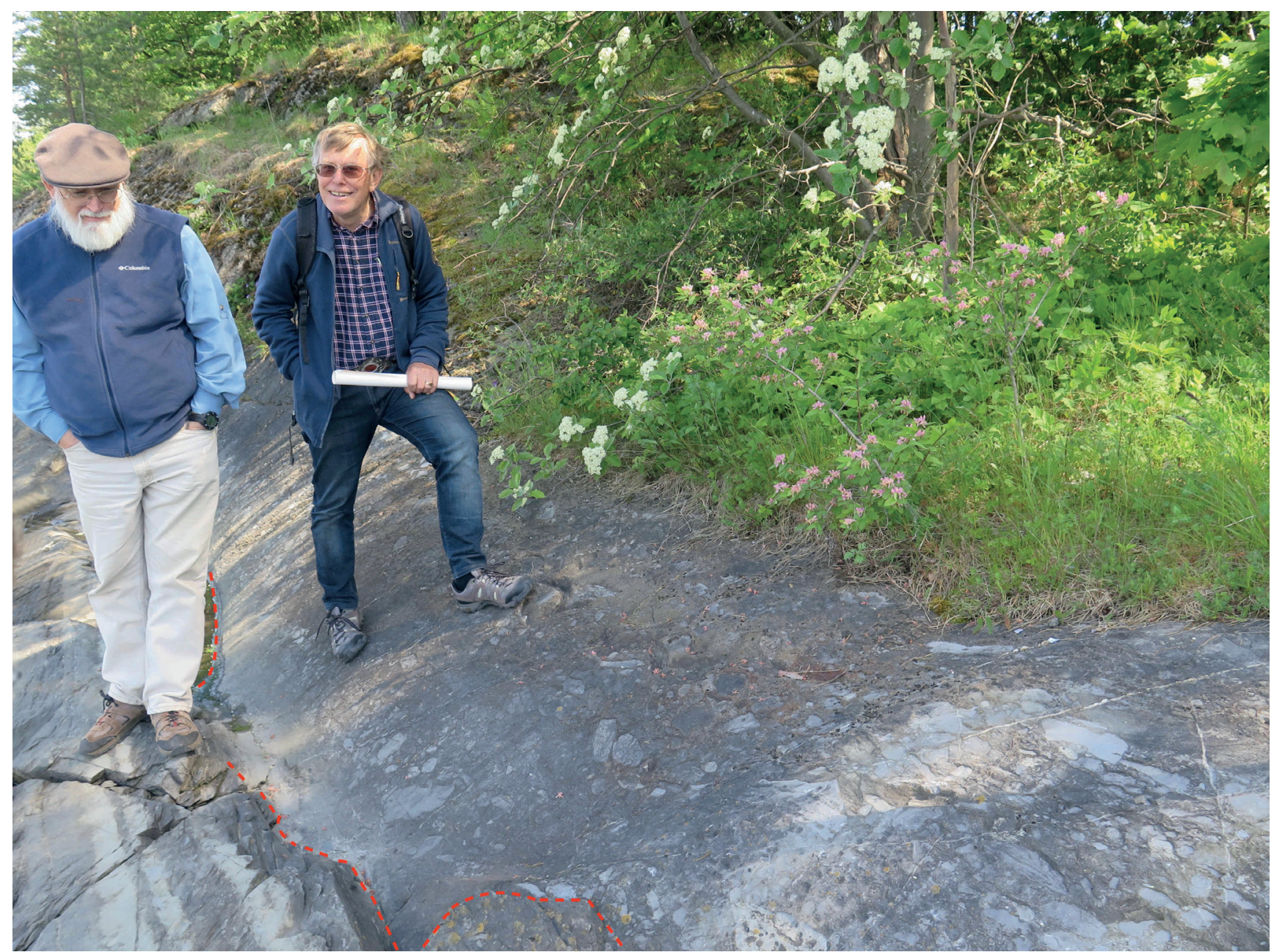

Figure 11. The basal type section (see red line) of the Kalvøya Member of the Langøyene Formation at Bikkjebukta, Sandvika, with the senior author and one of the junior authors.

distal sandstones and siltstones. The total thickness of this unit varies from about $4 \mathrm{~m}$ by the road to about $2 \mathrm{~m}$ at the top of the section. The interval contains abundant brachiopods, particularly Brevilamnulella kjerulfi, and also halysitid and rugose corals through a gradual shallowing up section.

Unit 3 starts with a $30-40 \mathrm{~cm}$ downlap succession seen at road level, thinning rapidly towards the top of the section. There is a thin conglomeratic horizon here also with small pebbles derived from the Palaeoporella limestone facies. The remaining part of this section (close to $4 \mathrm{~m}$ ) consists of light-grey, fine bioclastic and quartz sand in a darker siltstone.

Unit 4 starts with a channel cutting into the second unit fill. It is about $60 \mathrm{~cm}$ thick at road level and thins to about $20 \mathrm{~cm}$ at the top of the section, migrating in that direction. Immediately above are abundant brachiopods of different types. The remaining part of the unit fill is complex and comprises several channels in a cut-and-fill setting towards the top of the stratigraphic interval. Some intervals show ripple marks. There appears to have been a high-energy, very shallow-water environment in this cut-and-fill setting. Several smaller aggrading channels are present, with their axes more or less in the middle of the section wall. These channels appear to be controlled by synsedimentary faults within the palaeovalley and the overlying Solvik Formation is downwarped into it. The uppermost part of the fill succession features about $2 \mathrm{~m}$ of oolitic calcareous sandstone with small quartz grains, waning towards the top of the section. The upper metre of the section viewed from the road just below the Solvik Formation appears to be a mega ripple.

The top of the third unit fill shows erosion close to the road of about 1-2 m, and the overlying Solvik Formation onlaps the top. This may indicate that the deposits of the palaeovalley fill were exposed and eroded prior to deposition of the Solvik Formation. If so, the result of eustatic or isostatic processes cannot be differentiated. Ordovician brachiopods have been collected up to 21 $\mathrm{m}$ into the Solvik Formation, whereas at Spirodden they occur up to $40 \mathrm{~m}$ into the Solvik Formation (Baarli, 2014).

This section is one of the few areas with palaeovalley fill parallel to the regional strike trend. It also differs 

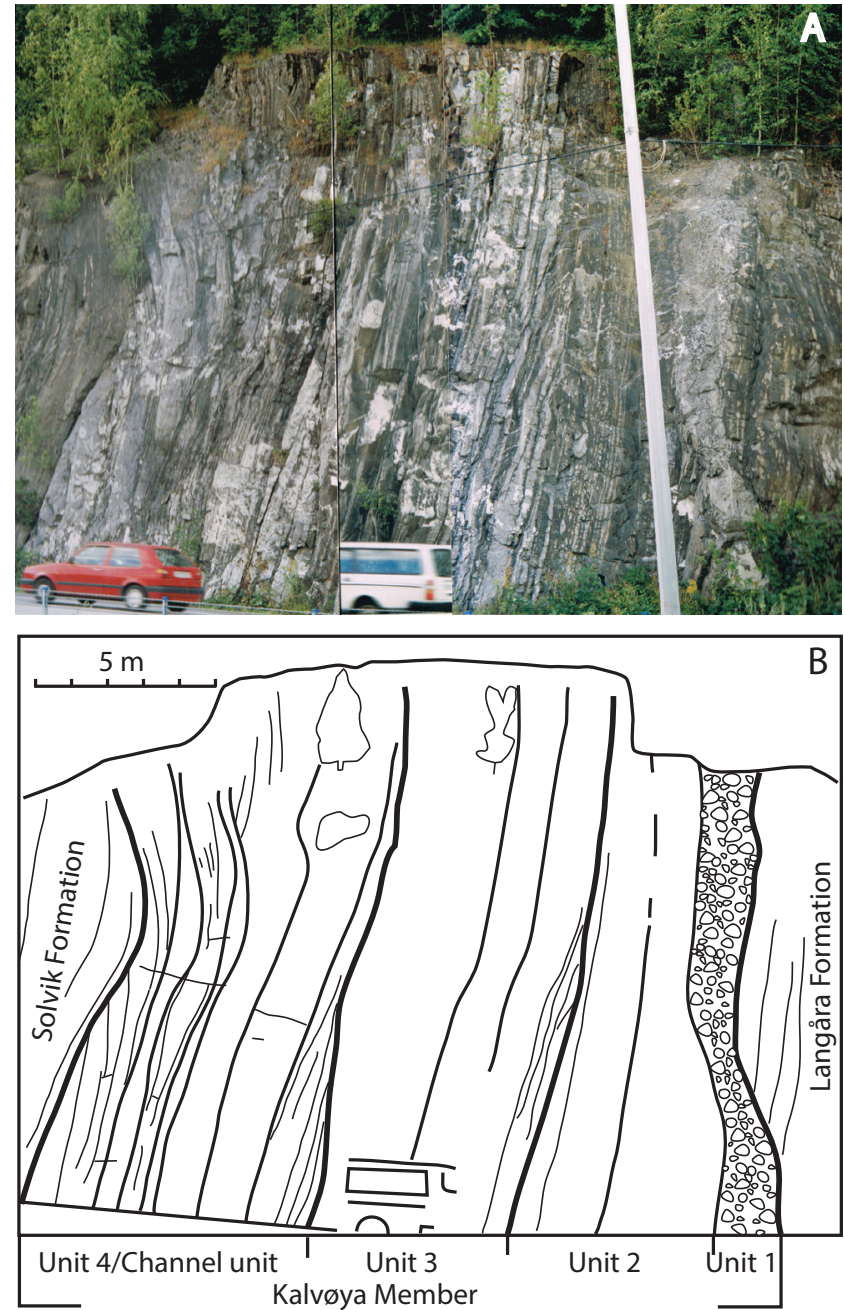

Figure 12. Road section at Drammensveien west of Holmen (Loc. 31; Fig. 1). (A) Photomosaic showing the Langåra Formation (right) cut by the basal conglomerate of the Kalvøya Member with the Solvik Formation (left) draping down into an unfilled channel on the top of the Kalvøya Member. (B) Line drawing of the units with the main units interpreted.

from other palaeovalley fills found in the area, as does Rognskjær and Kloåsen at Hvalstad.

\section{Nesøya West (Vestre Vei 55B)}

(Asker; Loc. 32; Figs. 1 \& 7)

The section is located at the seashore and is exposed as the southern limb of an anticline. A comparable section also can be studied in the road section along Vestre Vei just a hundred metres farther inland, and here the entire Brønnøya Bed is exposed showing that very little of the bed is missing at the seashore.

Unit 1 features conglomerate near the base of the section and marks the top of the anticline at the seashore. It contains pebbles of the Palaeoporella facies and oolitic limestone, and coarse quartz grains typical of the Pilodden Member in the Langøyene Formation. The base of the conglomerate cannot be seen at sea level, but is found on the road above.
Unit 2 lies directly above the conglomerate with an approximately $1 \mathrm{~m}$-thick interval of medium sandstone ('storm sand unit') as seen on Kalvøya, typical of the lower part of the Kalvøya Member. The remaining 2-3 m of the section towards the south is covered. There may be a fault in this area. The unit continues from a concrete wall by a red shed for just over a metre. The individual beds are fine to medium sand, about $5-7 \mathrm{~cm}$ thick, separated by equal thicknesses of fine siltstone.

Unit 3 starts with a siltstone interbedded with 3-5 $\mathrm{cm}$-thick limestone layers, usually micritic. A few thin siltstone beds $4-5 \mathrm{~cm}$ thick occur in places. Rugose corals are common in the lower part and brachiopods (sowerbyellids, orthids) increase in number and diversity upwards in the section. Small crinoid ossicles are present throughout the unit; some of them very distinctive. Trace fossils (Planolites) increase upwards, and at $2.7 \mathrm{~m}$ below the top of the member there are trace fossils consisting of calcite plates set in a vertical chevron shape. This is the same type of trace fossil found at Kalvøya.

The top of the Kalvøya Member consists of three distinct planar limestone beds; a $5 \mathrm{~cm}$-thick micritic bed, followed by $21 \mathrm{~cm}$ of siltstone, then a $7 \mathrm{~cm}$ micrite bed, followed by $17 \mathrm{~cm}$ of siltstone and topped by $20 \mathrm{~cm}$ of micritic limestone (possibly two beds with very little silt in between). This is comparable to sections at both Kalvøya and Brønnøya.

Unit 4 consists of the Brønnøya Bed represented by a nodular limestone in a dark-grey mudstone, about $5 \mathrm{~m}$ of which can be followed before the section ends at the sea. The lower part consists of about $3 \mathrm{~m}$ of densely nodular limestone, dominated by trilobites (Bumastus sp.), Chondrites traces and orthid brachiopods, particularly in the lower part. Towards the upper part of the section the limestone nodules become more scattered in the mudstone and fossils become less common. Eospirigerina was found together with a small stick bryozoan and a cephalopod about $5 \mathrm{~m}$ above the base of the Member. Chrondrites occurs throughout, but Bumastus becomes less common towards the top.

\section{Holmen islet (Asker; Loc. 27; Figs. 1 \& 10)}

The section on the small island at the outlet of the river Neselven has cut deeply into the Palaeoporella beds of the Husbergøya or Langåra formations. This was one of the localities where Brenchley \& Newall (1975) interpreted the section as two tidal channels, partly because of collapse of the channel sides into the channel. However, the current authors see this as an incised valley where the side of the valley slid into the bottom of the deposits due to clay that was washed out between the Palaeoporella limestone beds. The fill, which is about $2-3 \mathrm{~m}$ thick, consists of Langøyene-type facies and bioclastic material, possibly reworked lithologies from the Langøyene 


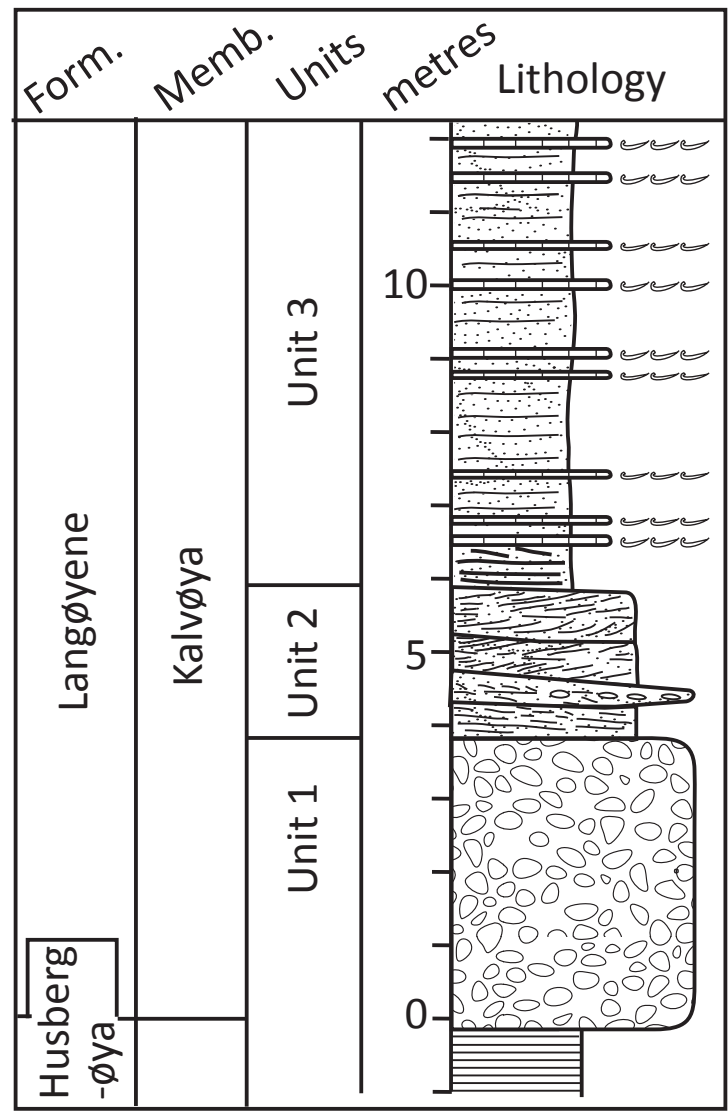

Figure 13. Section at Kloåsen, Hvalstad (Loc. 37; Fig. 1). The exposed and excavated section shows the lower and middle parts of the Kalvøya Member, Langøyene Formation.

Formation, including oolitic rock fragments. A second phase of infill in the palaeovalley again comprises conglomeratic boulders from the Langøyene Formation with rock fragments of different types, some containing rugose corals, others with oolitic facies and some with calcareous sediments including millet-seed sand. A study of the composition of the conglomerate indicates the presence of inter alia oolitic material. The succession on top of the second conglomerate is not exposed at Holmen, and complex deformation outside this area makes it difficult to estimate the type of lithology present above the second conglomerate. However, the section along strike continues across Landøya towards Nesøya with several small exposures including conglomerate and fill from the Kalvøya Member of the Langøyene Formation.

\section{Kloåsen, Hvalstad (Asker; Loc. 37; Figs. 1 \& 13)}

The section is located on the southern limb of a fold exposed in the ridge above Hvalstad Station. It was termed 'Brauers udsigt' by Kiær (1902). The base of the disconformity is formed by conglomerate that cuts well into the Husbergøya Formation.

Unit 1 features conglomerate $3.85 \mathrm{~m}$ in thickness. Boulders in it derive from the Palaeoporella beds of the
Langåra Formation mixed with abundant millet-seed quartz grains $1-2 \mathrm{~mm}$ in diameter, in places $2-3 \mathrm{~mm}$. Quartz grains occur throughout the conglomerate. There is no clear sorting of the pebbles, which may vary in diameter from 2 to $5 \mathrm{~cm}$. Redeposited rugose corals are common in the conglomerate.

Unit 2 sits immediately above the conglomerate as a 2 $\mathrm{m}$-thick interval with coarse to very coarse channellised sandstone beds with frequent millet-seed sand grains throughout. No fossils are found in this interval.

Unit 3 includes a more than $7 \mathrm{~m}$ thickness of medium sand interbedded with 5-10 $\mathrm{cm}$-thick bioclastic limestone layers with millet-seed quartz grains. The limestone layers are spaced approximately one bed in every half metre. The lowermost part of this interval consists of laminated, partly rippled, fine- to-medium sandstone beds. The laminae are on a millimetre scale, and a few intervals appear as 'silty paper shale'. A $5 \mathrm{~cm}$-thick cross-bedded limestone bed tops this lowermost unit. No fossils have been found in this interval. From $13 \mathrm{~m}$ above the base of the conglomerate the slope is covered by soil.

\section{Rognskiær (Asker; Loc. 30; Figs. 1 \& 14)}

At this locality, an island exposure comprises a relatively thin Hirnantian section (about $12 \mathrm{~m}$ in thickness) since the valley incision has removed most of the underlying strata.

Unit 1 at the base of the incision is formed by a conglomerate $>1 \mathrm{~m}$ thick that has filled a widely eroded disconformity cut into the Hovedøya Member in the Skogerholmen Formation (Owen et al., 1990, p. 33-34). The succession is complex and appears in places to have been subaerially exposed.

Unit 2 follows the conglomerate as laminated siltstone and sandstone, in part showing ripple-drift laminations, and channelled interbeds thickening from $80 \mathrm{~cm}$ in the northeast to $4 \mathrm{~m}$ thickness in the middle of the 105 $\mathrm{m}$-long section. Thereafter, the section thins farther southwest to $2.5 \mathrm{~m}$ returning to laminated sandstone. The quartz sandstone is mostly coarse, but contains calcareous siltstone pebbles, well rounded in certain horizons. Locally, they may form a zone up to $20 \mathrm{~cm}$ in thickness. No fossils have been found in this unit.

Unit 3 consists of a thin brownish-green silty shale within 70 to $180 \mathrm{~cm}$-thick laminated sandstone beds without fossils but with common mud cracks that characterise this unit. In places there are ripples. The unit may represent a nonmarine sediment or lagoonal deposit, but no microfauna has been recovered. The top of this shale is eroded in some areas over the entire $105 \mathrm{~m}$-long section. It is overlain by $0.5 \mathrm{~m}$ of conglomerate (Fig. 14). 


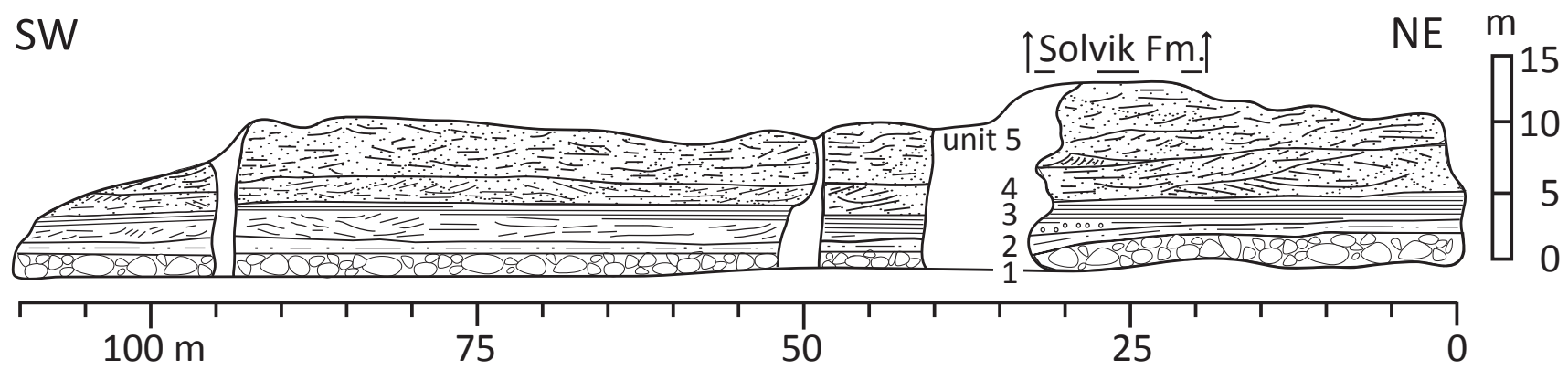

Figure 14. Sections from NE to SW at Rognskjør, Asker (Loc. 30; Fig. 1) of the Kalvøya Member. The boundary with the Solvik Formation dips below the sea. The base of the formation is eroded into the Hovedøya Member of the Skogerholmen Formation. Five units of the Kalvøya Member can be distinguished and partially correlated.

Unit 4 may be traced laterally for more than $20 \mathrm{~m}$, but then grades into coarse sandstone. The sandstone above the shale is coarse to very coarse (sand grains up to $1-2$ $\mathrm{mm}$ in diameter) and also contains calcareous pebbles throughout, but more commonly in the lower part. Some distinctive erosional surfaces are found in the northeastern part of this unit. Unit 4 is about $3 \mathrm{~m}$ thick in the northeast but thins to a thickness of one metre over a distance of $107 \mathrm{~m}$ farther to the southwest.

Unit 5 is a high-energy sandstone probably deposited in a shore-face setting. It lies above units 1-4 to comprise a section of $5 \mathrm{~m}$ in the west and $8 \mathrm{~m}$ in the east (Fig. 14). A marked erosional surface occurs at the base of unit 5 along the entire $107 \mathrm{~m}$ profile of the island. This erosional surface may represent a second lowering of the sea level, due either to eustasy or to uplift. The contact with the overlying Solvik Formation occurs below present sea level.

\section{Bierkøya SW (Asker; Loc. 41; Figs. 1 \& 15)}

The succession exposed in the southwestern part of Bjerkøya is similar to that of Rognskjær. At Bjerkøya, the incision also cuts down into the lower part of the Hovedøya Member of the Skogerholmen Formation. The palaeovalley was subsequently filled with coarse sediment.

Unit 1 is a $4 \mathrm{~m}$-thick polymictic conglomerate containing pebbles of oolitic limestone (Pilodden Member, without millet-seed quartz), Palaeoporella limestone and crossbedded medium sandstone (Høyerholmen Member). The matrix typically consists of coarse quartz grains (1-2 $\mathrm{mm}$ in diameter). Fossils are very common in the conglomerate and appear to be reworked from mostly Katian strata.

Unit 2 comprises approximately $6 \mathrm{~m}$ of medium-tocoarse sandstone, commonly with some conglomeratic horizons and cross-bedding from a shallow-marine, shore-face setting along the western line of strike on the island. Fossils are rare, but rugose corals occur about 6-10 $\mathrm{m}$ above the base of the conglomerate.
Unit 3 is complete at the section near the windmill (Loc. 41; Fig. 15) where there is a slightly fining-upward trend dominated by cross-bedded sandstones and planar beds

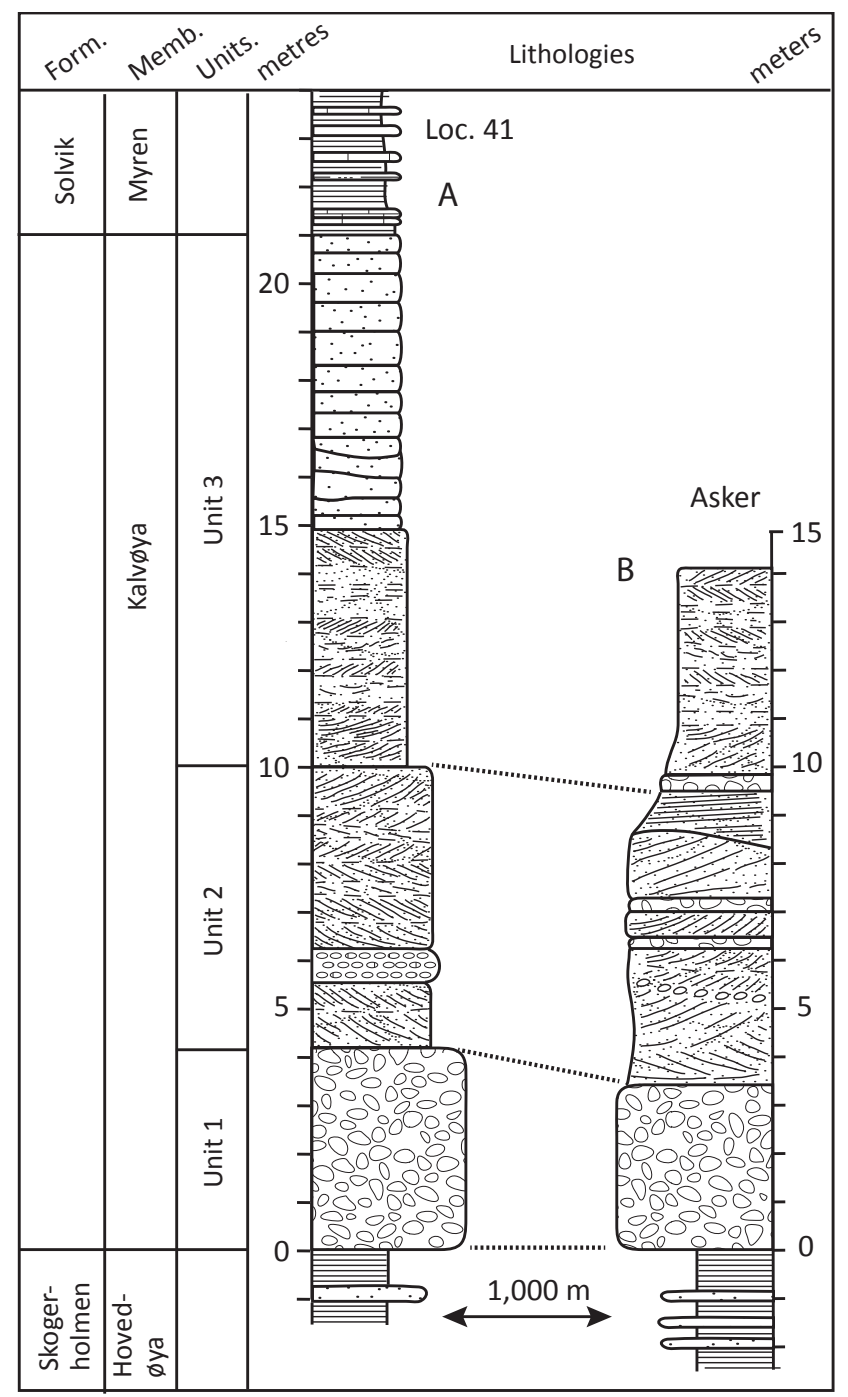

Figure 15. Two sections at Bjerkøya, Asker, showing the Kalvøya Formation cutting down in the Hovedøya Member of the Skogerholmen Formation. (A) Near the windmill at the western side of Bjerkøya (Loc. 41a; Fig. 1) and (B) SW Bjerkøya (Loc. 41b; Fig. 1). The distance between the localities is about $1 \mathrm{~km}$. 
of fine sand, $11 \mathrm{~m}$ thick. There is a sharp boundary with the overlying Solvik Formation. The Kalvøya Formation here is $21 \mathrm{~m}$ in total thickness. No Brønnøya Bed sediments were found at this locality.

In the northwestern part of Bjerkøya, the Høyerholmen Member of the Langøyene Formation is present below the Solvik Formation. Here, structural deformation is complex and there are rapid facies changes in some of the coarse sand units, thus making detailed correlation difficult.

Road section at Slemmestadveien, Vettre, (Asker; Loc. 42; Figs. 1 \& 16)

A road section exposing an anticline along Slemmestadveien just north of Vettre shows the contact between the palaeovalley fill and the underlying Pilodden Member of the Langøyene Formation, where the member displays an atypical facies development at the top. No conglomerate occurs at the base of the Kalvøya Formation at this locality, but a distinct erosional cut within the top of the Langøyene Formation is accessible (Fig. 16). About $3 \mathrm{~m}$ of the Kalvøya Member is exposed above. At this locality there are at least three shallowmarine successions with medium-to-coarse sandstone showing parallel laminations and particularly in the upper part cross-bedding and some channelling. These are interpreted either as shore-face or supratidal, highenergy deposits. The overlying contact with the Solvik Formation is not exposed, but the Solvik Formation is present on the west side of the road on the down-thrown nose of the anticline. No exposures of the Brønnøya Bed have been found at this locality.

\section{Other localities}

In addition to these localities, there are several others with lesser exposures in Asker and Bærum. Some of the localities were described by Brenchley \& Newall (1975), including Torbjørnsøy. There, shales of the Solvik Formation drape down into a partly unfilled incision. Many of these localities seem to be part of a complex system of interconnected smaller valleys, generally less than $100 \mathrm{~m}$ across. Mikael Calner studied samples from the fill of at least one incised valley on Brønnøya, and this coincides with a falling limb of the $\delta^{13} \mathrm{C}$ trend (M. Calner, pers. comm., Dec. 2014), e.g., a latest Hirnantian age.

The incised valleys usually start with an infill of conglomerates and with a variety of other sediments that fill up-section before being covered by shales belonging to the Solvik Formation. In the Bunnefjorden area south of Hovedøya, incised valleys have been found on Rambergøya and Langøyene south (Sandbakken, 2014; Franeck et al., 2015). Conglomerates and successive fill have also been found on Malmøya and may be present on other islands in the Bunnefjorden area, including Ormøya. In several of these areas, more than one conglomeratic horizon has been observed. Franeck et al. (2015) proposed that the three main phases of erosion in the Bunnefjord area may be connected to glacio-eustatic sea-level changes during the Hirnantian. Stanistreet (1978) indicated that these conglomerates might be related to what he called the Bunnefjorden fault system (Stanistreet, 1983) and synsedimentary faulting. Lervik (1969) recorded several localities with conglomeratic horizons In the Bærum area.

There exists only a single conglomerate, the basal conglomerate facies, within the type section and also at the section at Hovedøya. The conglomerate lining the base at Hovedøya contains blocks of the Pilodden Member, and the incision and fill therefore postdates

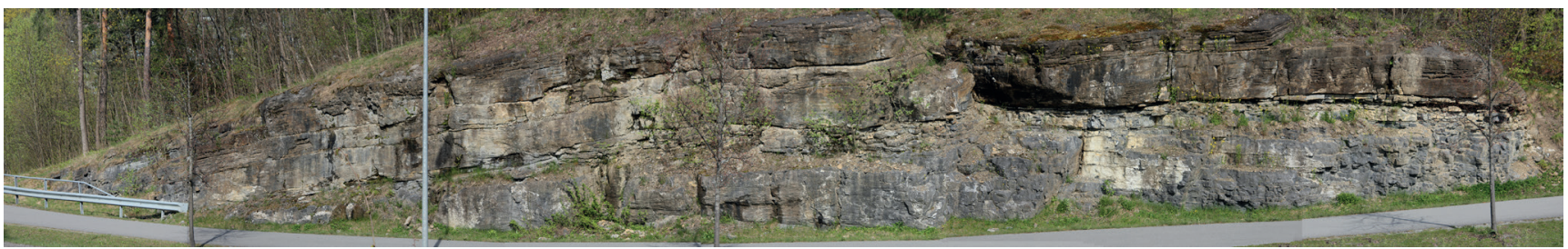

A

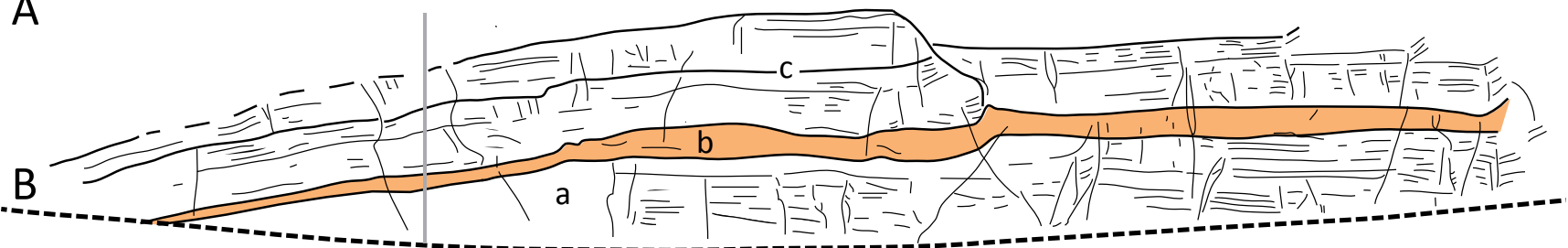

Figure 16. Anticlinal road section at Slemmestadveien at Vettre (Loc. 42; Fig. 1). (A) Photomosaic of the section showing lateral development of the upper Langøyene Formation. (B) Drawing of the same where bed (a) of the Pilodden Member is the typical development of thick oolitic limestone followed by bed (b) of the same member (coloured and approximately $1 \mathrm{~m}$ thick) consisting of sandstones and mudstones. Following above with an erosive base are sandstones of the Kalvøya Member (c) that is quite thin at this locality. Note the lack of conglomerate at the bottom of the Kalvøya Member. 


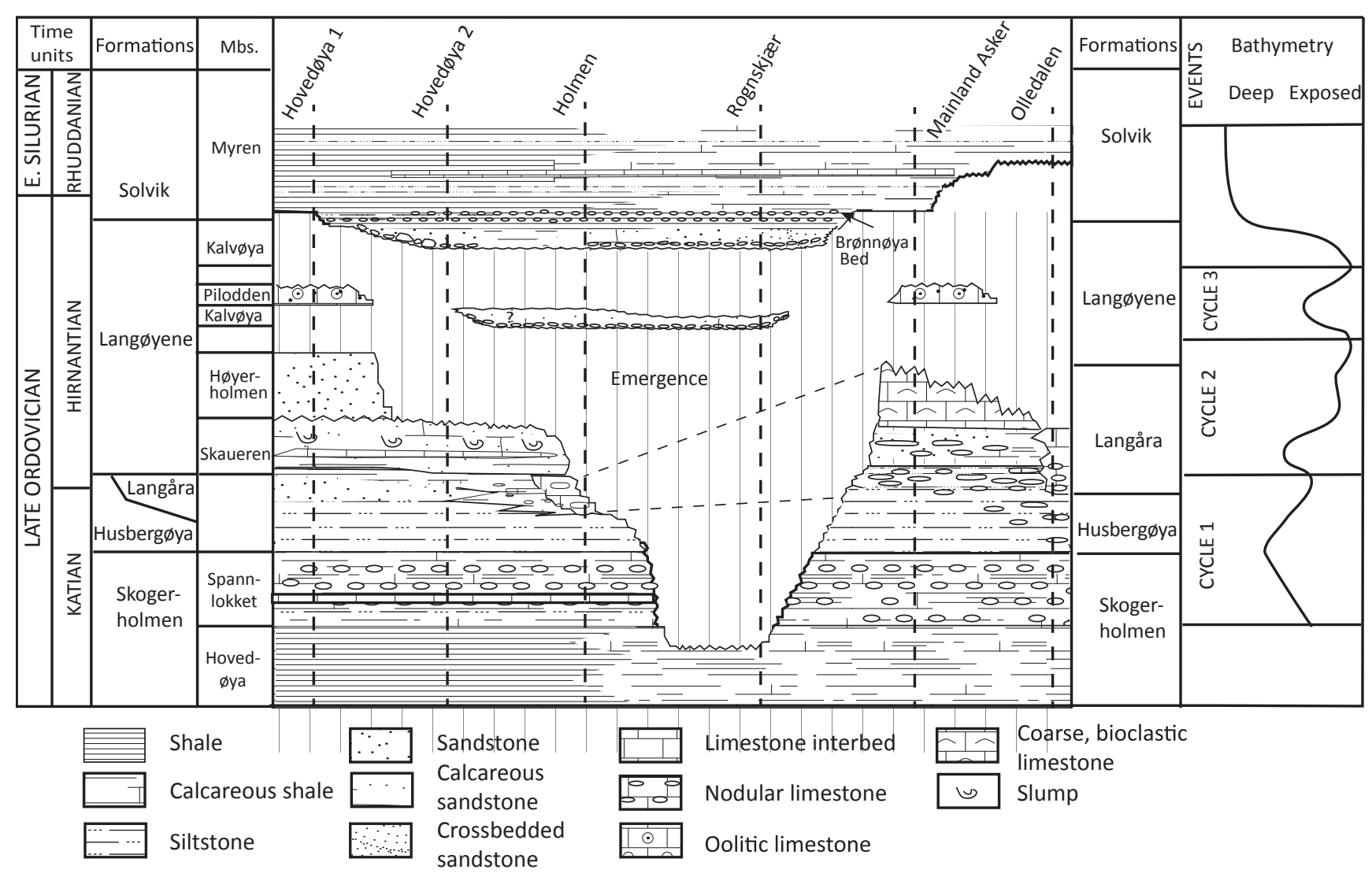

Figure 17. Six representative sections (dashed lines) across the Oslo-Asker area shown from east to west. The first two represent the inner, easternmost islands. Hovedøya 1 displays interchannel sections, Hovedøya 2 sections with valleys. Holmen and Rognskjor represent valley sections progressively farther west, whereas Asker and Olledalen represent intervalley sections in the western mainland and far western parts, respectively. The right-hand column shows interpreted sea-level changes. Note that several valley sections would be crossed along an east-west line through the region, only one of which is shown here in an idealised section.

deposition of that unit (e.g., dated as late Hirnantian). At Holmen to the west (Loc. 27; Figs. 1 \& 10), the Kalvøya Formation occurs at two stratigraphic levels separated by strata of the Langåra Formation. The sections at Vakås, Bjerkøya and Rognkjær all contain more than one conglomeratic horizon and erosion surfaces within the Kalvøya Member. This may be a manifestation of the multiple incision levels found south of Hovedøya at Rambergøya and Langøyene (Franeck et al., 2015). In the first two cases, the last episode of valley incision eroded and obliterated the earlier valley incisions. Where fill from earlier episodes remains intact, fossils are lacking. Periods of incision would be likely where there are district-wide erosion surfaces as found at the base of the Høyerholmen Member and especially at the base of the Pilodden Member (Fig. 3).

\section{Subaerial exposure in the central Oslo Region}

Fig. 3 shows there is no obvious gap in strata from the upper Katian of the Oslo-Asker district, suggesting that the area was continually submerged by the sea. However, evidence for periods of nondeposition can be observed. According to Brenchley \& Newall (1975), a brown siltstone facies can be traced across the area and used as a chronostratigraphic marker. These siltstones occur in the middle of the Langara Formation in Katian strata. They were developed as a hardground or firm ground at Holmenskjæret immediately above the Palaeoporella limestone in brown, silty shale beds with Holorhynchus giganteus. Mudcracks in the Langåra Formation in the same kind of facies are observed at Konglungveien 97. The same facies is exposed near the top of the Husbergøya Formation in early Hirnantian strata to the east on the islands (Fig. 3) and may also represent a period of nondeposition. Here, the silty shale beds are dominated by 'Heliocrinites balticus' and the tops are completely reworked by animals that churned the sediments. Clearly, the extent of the brown siltstone facies is not synchronous, but seems to denote a shallowing trend that followed a shoreline as it retreated eastward. Possibly the source area was temporarily cut off.

Later during the Hirnantian, obvious erosional gaps were commonly developed (Figs. 3 \& 17). With repeated periods of emergence and erosion of incised valleys of varying depth, a pattern of strong topography and diachronous boundaries of lithostratigraphic units are to be expected. 


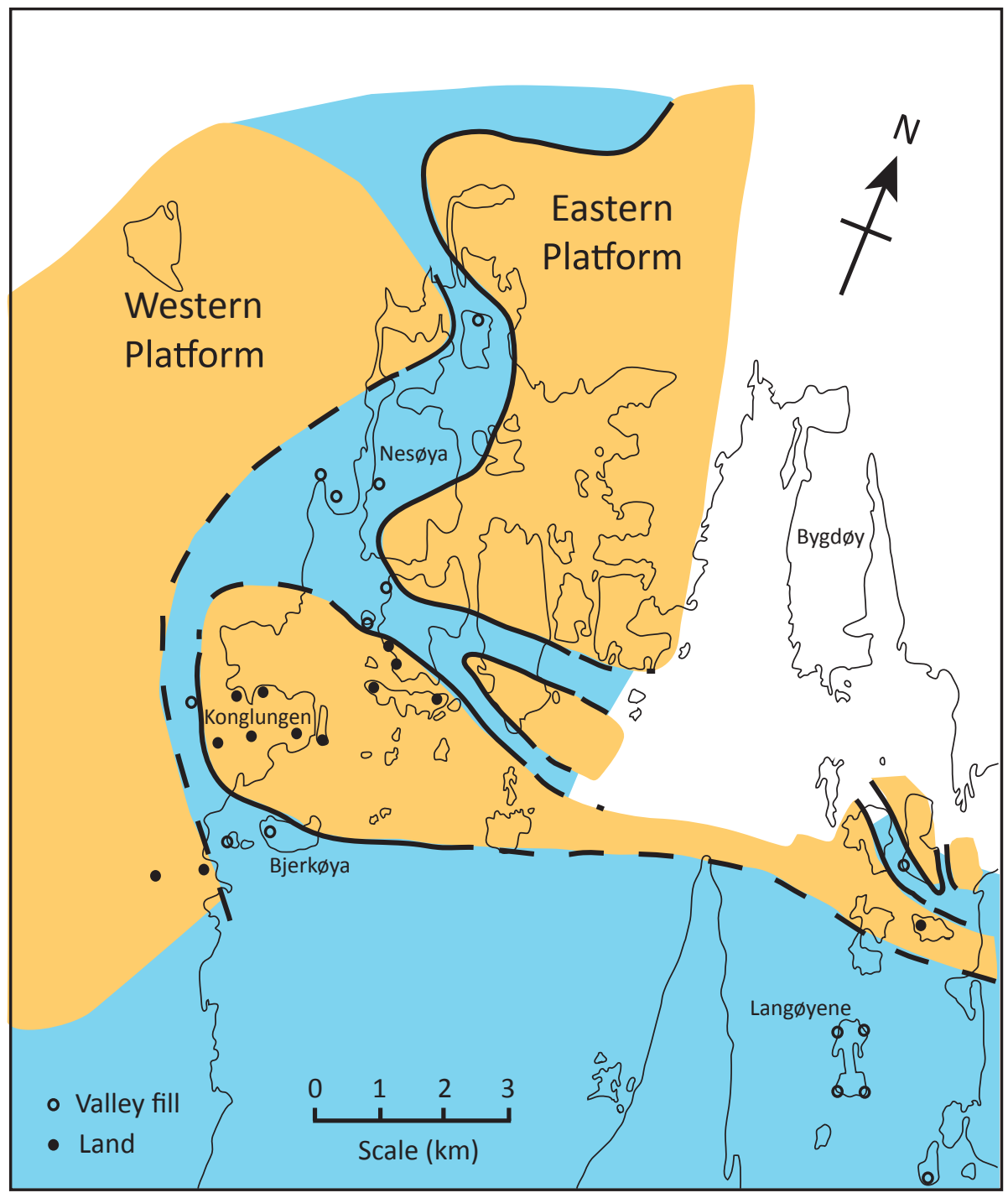

Figure 18. Possible representation of paleogeography of the Oslo-Asker district towards the end of the Hirnantian with the valley filling of the Kalvøya Member, Langøyene Formation shown in blue and the land areas in orange. The palinspastic reconstruction is modified from Stanistreet (1978).

Shore-face deposits of the Pilodden Member are preserved on Spannslokket, Asker (Isaksen, 1982, p. 116), on Skogerholmen and on Høyerholmen (Tonstad, 1983), and at Vettre, Kloåsen and Rognkjær (this contribution). The Pilodden Member displays oolite bars, tidal flats and in some areas possibly supratidal deposits. Both below and above the Pilodden Member, there appear to be major breaks in the depositional history (Fig. 3). The relative sea-level drop following the deposition of that member naturally would have resulted in subaerial exposure, either locally or regionally. Above this break there may be different lithologies filling incised valleys with sediments of the Kalvøya Member. In areas without incisions, the Solvik Formation lies directly on the Langøyene or Langåra formations (Fig. 3).

The extent of subaerial exposure in the central Oslo Region remains unknown, but studies in Oslo-Asker and Bærum demonstrate the preservation of several incised valleys. These became widened towards the northwest. In particular, the upper fill deposit in the Hovedøya palaeovalley was transported from the south towards the north. The Kalvøya strata through the Nesøya and Holmen sections appear to be connected as part of a larger palaeovalley fill more than $10 \mathrm{~km}$ long and possibly a few kilometres wide and trending approximately NE-SW. The overall relationships of all sections in this study may be summarised in a palaeogeographic reconstruction (Fig. 18), although with so few points that other interpretations are possible.

\section{Relative sea-level changes}

The Husbergøya Formation shows an abrupt change from nodular limestone layers of the Skogerholmen Formation to shales denoting a deepening. The formation was deposited in an outer shelf setting 
(Brenchley \& Marshall, 1999). There is a gradual increase in thin calcareous siltstones up through the formation. Furthermore, there is a faunal change from a Tretaspis to a Onniella-Tretaspis association that Brenchley \& Cocks (1982) interpreted as a slight shallowing (Cycle 1; Fig. 17). The change corresponds to a glaciation phase linked to a low stand in the subtropical regions just above the Katian-Hirnantian boundary (Bergström et al., 2014; Ghienne et al., 2014; Harper et al., 2014).

The Skaueren Member of the Langøyene Formation represents a minor transgression as part of a sea-level rise. It is succeeded by a regression demonstrated by an erosion surface at the base of the Høyerholmen Member with a high sediment input in shallow water during deposition (Cycle 2; Fig. 17). At the close of deposition in the Høyerholmen Member, there appear to have been subaerial exposure of larger areas indicated by angular unconformities. This emergence is regarded as an expression of maximum HICE and a draw-down of sea level during the glaciation (Bergström et al., 2006). There are several phases of channel fill, and an early phase of incised valley formation is likely at this time.

The Pilodden Member has been correlated with the late Hirnantian M. persculptus graptolite Biozone recorded in the Leemon Formation in the Cape Girardeau area of Missouri, USA, the Saldus Formation in Estonia and the Skultorp Member of the Loka Formation in Västergötland, Sweden, respectively (Bergstöm et al., 2006). These formations also reflect oolite deposition bounded by gaps similar to what is recognised in the Pilodden Member in the Oslo area. The Pilodden Member, thus, represents a slight high-stand or warming period between two drops in sea level during the end of the HICE interval and the channels were cut during the last low-stand after deposition of the Pilodden Member (Cycle 3; Figs. 3 \& 17). How long the last sea-level drop lasted is not known, but it resulted in the formation of the last of a series of incised valleys in Oslo, Asker and Bærum. The geographic extent of these valleys and the depth of bedrock into which they eroded were considerable.

The main phase of deposition of the Kalvøya Member (Late Hirnantian) represents a transgression resulting in the final fill of the palaeovalleys. Its full extent and composition are not mapped, but it is present at several places in Oslo, Asker and Bærum. At Hovedøya, blocks of the Pilodden Member line the bottom of the Kalvøya Member followed by strata devoid of fossils and an erosional contact with marine fossils above. This transition may signify the changeover from river deposits to eroded beach and marine deposits. The sea-level rise that resulted in the terminal fill of the incised valleys continued into the Silurian. In certain places with valley fill, as at Nesøya, no gap between the fill and the Solvik Formation is observable. The filling history there may be more complex due to possible active faulting, particularly in the Bunnefjorden area (Stanistreet, 1983).
The incised valley-fill strata indicate that there was a complex succession of relative sea-level drops and associated erosion succeeded by sea-level rises and subsequent development of marine infill in the incised valleys. The details and complexity of these events are known in enough detail to outline a preliminary scheme and put together the succession of events as now understood (Fig. 17).

\section{Hirnantian topography across the Oslo-Asker district}

Kiær (1902) established the presence of facies belts across the Oslo Region parallel to the Caledonian front and most subsequent workers in the Oslo Region have recognised these. During the Ordovician, there existed a very gentle slope across the Oslo-Asker district with shallower areas to the west and deeper areas to the east and south. This was also the case at the transition between Katian and Hirnantian, as shown by the dark siltstone facies seen at Holmen to the west (belonging to the upper Katian) and at Hovedøya to the east (belonging to the lower Hirnantian) as a consequence of shoreline retreat towards the deeper parts in the east.

Sea level was lower during most of the Hirnantian and during times with minimum sea level valleys were incised and the intervening areas were eroded. The final, endHirnantian, sea-level rise was responsible for flooding and infill of the valleys. The initial flooding must have been caused by a very rapid sea-level rise. The age of the base of the Solvik Formation is latest Hirnantian both at Hovedøya and at Konglungø (Fig. 3). The areas in between exhibit basal Solvik strata of a seemingly coeval age even though fossil assemblages indicate varying depths. Higher in the Rhuddanian, the same gentle slope from west to east was again established (Baarli, 2014).

The situation on the mainland in Asker, west of the islands, is different. At Vettre (Loc. 42; Fig. 1), a sandy shoreline developed. Farther inland, the locality at Kloåsen (Loc. 37; Fig. 1) is limited, so it is difficult to say if there was an incised valley. It could just as well constitute a boulder shore, because the conglomerate is monomictic and derived from the underlying formation. Kaljo et al. (2004) investigated a section at Sem (Loc. 45; Fig. 1). They found the $\delta^{13} \mathrm{C}$ excursion was less complete here as compared with Konglungø (Loc. 16; Fig. 1), where we know the base of the Solvik Formation was deposited during the late Hirnantian. They suggested the existence of a larger gap at Sem. Even farther west in Olledalen (Loc. 36; Fig. 1), the gap is substantial and the area was first flooded in the late Rhuddanian (Coronograptus cyphus graptolite Biozone, see Electronic Supplement). This is in agreement with what Baarli (1988) found for the base of the Solvik Formation at Toverud in Sylling, approximately $4 \mathrm{~km}$ north of Olledalen. Topographically, this appears to have been a well exposed high that 
gradually became flooded until it was fully submerged in the late Rhuddanian. The scenario may represent the earliest manifestation of a minor bulge that moved across the Oslo Region, parallel to the Caledonian facies belts throughout Llandovery time (Baarli, 1990; Worsley

\section{Warm- and cold-water Hirnantian faunas in the central Oslo Region}

The Hirnantia association occurs at the very top of the Husbergøya Formation and extends just a few metres into the Skaueren Member of the overlying Langøyene Formation. The Dalmanella association occurs above in the lower parts of the same formation (Brenchley \& Cocks, 1982). The Holorhynchus, Dalmanella, and more commonly the Cliftonia-Hindella associations, occur in the Langåra Formation. The latter two faunas are typical of the cold-water Kosov province (Harper \& Hints, 2016). This is in agreement with the onset of glaciation and cool periods during the early and middle phases of the Hirnantian. The fauna found in the Pilodden Member is poor, but Brevilamnulella occurs in large numbers in a few localities (Cocks \& Brenchley, 1982). This is a warmwater element only found elsewhere in Laurentia that together with the occurrence of oolite banks, indicates a warming period. It is a part of the Laurentian Edgewood fauna that Wang et al. (2016) showed to stratigraphically follow the typical Hirnantian fauna. Faunas in the overlying Kalvøya Member are more diverse. These show a mix of cold- and warm-water elements and the latter are closely related to the Laurentian continent (Harper \& Hints, 2016). Mucronaspis occurs throughout Hirnantian strata in the Oslo Region including the Kalvøya Member. This trilobite is common in the lower parts of Hirnantian strata in the East Baltic and there does not extend into the upper Hirnantian (Hints et al., 2012). However, it is found in the Leemon Formation in Illinois as part of the Edgewood fauna. The fauna in the Brønnøya Bed and further into the lower parts of the Myren Member retains many Hirnantian elements, although the shallowwater rhynchonellids are missing and new Silurian faunal elements are present. These gradually replace the old elements during Rhuddanian 1 (Baarli \& Harper, 1986; Baarli, 2014).

\section{Comparison with other areas}

Ghienne et al. (2014), working in Morocco off the Ordovician polar cap and also in Anticosti, Canada, in a subtropical setting similar to that in the Oslo Region, found that the end-Ordovician glaciation mirrored the Pleistocene with repeated episodes of glaciations and interglacial warm periods. This resulted in a complex series of eustatic changes with three main glacial cycles. Many sections around the world are incomplete, as also found in the Oslo Region. However, the Oslo record shows repeated cycles of offlap and onlap. A result of such cycles may be emergence with karst features, incision of valleys and palaeovalley fills or erosion of rocky shorelines on land and erosion of submarine channels on the shelf. Kröger et al. (2015) linked deep karstic surfaces from the Boda limestone in Sweden to the Hirnantian glaciations. Karstic surfaces of Hirnantian age are also found in submarine channels in Meifod, central Wales (Brenchley et al., 2006). Incised valleys are described from the Upper Ordovician in Iowa (Johnson \& Baarli, 2007). On Anticosti island, two erosional subaerial surfaces were later flooded during the end Hirnantian (Ghienne et al., 2014). These must be drowned shorelines, whereas repeated erosion and channelling of the shelf due to glacio-eustatic changes are reported from the Czech Republic (Štorch, 2006) and Meifod, central Wales (Brenchley et al., 2006). The wellstudied incised channels found in the Oslo area were mainly river-cut valleys. However, more distal areas in the west may show more varied effects of the glaciation such as tidal channels or palaeoshorelines.

\section{Conclusions}

Field studies in Oslo, Asker and Bærum have revealed areas with variable relationships between the Langøyene and the Solvik formations and the filling of incised palaeovalleys. To faciliate the descriptions, four new members of the Langøyene Formation (Skaueren, Høyerholmen, Pilodden and the Kalvøya members) and a new bed within the Solvik Formation (the Brønnøya Bed) have been erected. The Kalvøya Member is defined for its extensive channel fill, whereas the newly described overlying Brønnøya Bed is found in the basal part of the overlying Solvik Formation

Many incised valleys in areas with deep erosion through the Langøyene, sometimes through the Husbergøya and into even older deposits, have been infilled with a basal conglomerate and other incised-valley deposits. There appears to have been a major NE-SW-trending valley from Holmen through Kalvøya and towards Bekkestua with minor valleys either perpendicular to it, or at a slight angle towards the south. The valley incisions deepened slightly from Holmen towards the southwest in the direction of Rognskjær.

Most areas were exposed above sea level at several times during the Hirnantian due to substantial eustatic drops in sea level, possibly combined with tectonic movements. Three cycles of sea-level change occurred during the Hirnantian followed by a major transgression starting at the end of the Hirnantian. The valleys were filled with sediment, some most likely from a fluvial source, but also were reflooded from the sea during the latest phase of the Hirnantian, while other areas to the far west were not flooded until well into the Early Silurian (Rhudddanian) at Olledalen in Asker. 
On the mainland in Asker and Bærum, bioclastic limestone layers form the areas between eroded valleys and contain faunas that suggest an early and mid Hirnantian age, whereas those on the islands contain oolitic limestone infused with 'millet seed' sand. These oolites contain warm-water faunas indicating a late Hirnantian age. Therefore, it is possible that the contrasting facies distribution represents two different carbonate factories. These two carbonate areas may not have been connected and the oolitic limestones were of different ages.

\section{Addendum}

The junior authors (Baarli and Johnson) re-established contact with Fredrik Bockelie in June 2013 during the post-conference field trip related to the Third Annual Meeting for the International Geoscience Programme
Project 591 held in Lund, Sweden. Conducted in joint sponsorship with the international subcommissions on Cambrian, Ordovician and Silurian stratigraphy, the meeting and field trip excursions ended in the Oslo region. Fredrik was one of the featured field trip leaders who led the group on visits to some of the islands in the Oslo fjord. Close contact was maintained during the following three years, including summer visits with Fredrik to see several more of the islands in the Oslo fjord under his active study. Baarli et al. (2015) presented preliminary results from this collaboration at the 5th International Symposium on the Silurian System and the 5th Annual Meeting of the IGCP 591 in Quebec City, July 8-11, 2015. During the last month before he passed away, Fredrik reached out to the two junior authors and they were able to finalise and submit the manuscript for review. The junior authors witnessed a steady change in Fredrik's thinking on possible ramifications on chronostratigraphy as an outcome of the highly developed physical stratigraphy he had charted in the

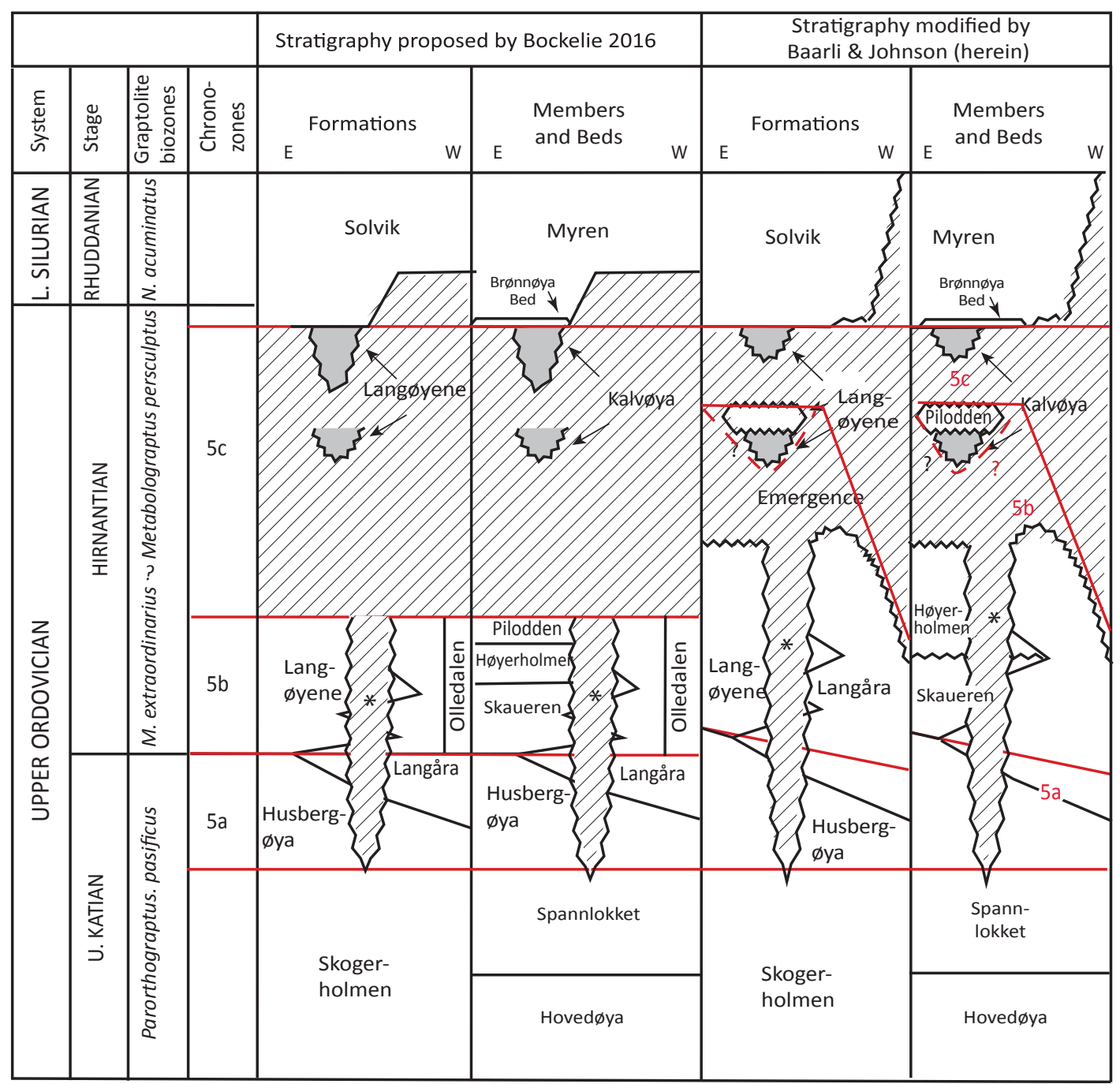

Figure 19. Physical and chronostratigraphy for the Upper Ordovician and Lower Silurian in the Oslo region with regional variations indicated on an E-W axis. Bockelie in 2016 favoured application of 'Etage' units, in this instance Etage $5 a, b$ and c, for his envisioned chronozones. The boundaries between these units are shown in red and highlight the differences between the senior author's usage and correlations by the junior authors. The amount of removed strata in channel incisions (marked by ${ }^{*}$ ) varies widely. 
Oslo region for over three decades. This addendum summarises the status of Fredrik's thinking at the time of his death in 2016, and compares it to the present outcome of the project (Fig. 19).

Acknowledgements. Several aspects of the observations were discussed with Brenchley and Newall while they were working in the Oslo area in the 1970s, and they inspired the senior author to search into the controversial aspects, including subaerial exposure. During the 1980s the senior author supervised students at the University of Bergen (Dag Isaksen, 1982 and K. Tonstad, 1983) on studies of the OrdovicianSilurian in Oslo-Asker. Prof. Ian Stanistreet has rendered important views on the incised valleys described above (pers. comm., 2012) as have discussions about the subject with Johan Petter Nystuen. In recent years, Johan Petter Nystuen, Snorre Olaussen, Bjørn Tore Larsen, Hans Arne Nakrem, Mikael Calner, and students supervised by the present authors at the Natural History Museum, Oslo (Martin Kjærsgaard and Martin Sandbakken) all contributed to obtain a better picture of the depositional system of the Ordovician-Silurian transition. David Bruton has always been available for constructive comments and discussions to improve the work. We are grateful for insightful reviews by Johan Petter Nystuen (University of Oslo) and Stig M. Bergström (Ohio State University) that helped to improve the final product.

\section{References}

Aldridge, R.J., Jeppsson, L. \& Dorning, K.J. 1993: Early Silurian oceanic episodes and events. Journal of the Geological Society 150, 501-513. https://doi.org/10.1144/gsigs.150.3.0501.

Baarli, B.G. 1988: Bathymetric co-ordination of proximality trends and level-bottom communities: A case study from the Lower Silurian of Norway. Palaios 3, 577-587. https://doi.org/10.2307/3514446.

Baarli, B.G. 1990. Peripheral bulge of a foreland basin in the Oslo Region during the early Silurian. Palaeogeography, Palaeoclimatology, Palaeoecology 78, 149-161. https://doi.org/10.1016/0031-0182(90)90209-P.

Baarli, B.G. 2014: The early Rhuddanian survival interval in the Lower Silurian of the Oslo Region: a third pulse of the end-Ordovician extinction. Palaeogeography, Palaeoclimatology, Palaeoecology 395, 29-41. https://doi.org/10.1016/j.palaeo.2013.12.018.

Baarli, B.G. \& Harper, D.A.T. 1986: Relict Ordovician brachiopod fauna in the Lower Silurian of Asker, Oslo Region, Norway. Norsk Geologisk Tidsskrift 66, 87-98.

Baarli, B.G., Bockelie, J.F. \& Nakrem, H.A. 2015: Ordovician/Silurian boundary in the Central Oslo Region. In Melchin, M.J. \& Jin, J. (eds.): 5th International Symposium on the Silurian System and the 5th Annual Meeting of the IGCP 591 - The Lower and Middle Paleozoic Revolution, Quebec City, July 8-11, 2015. Abstracts. Institute national de la Recherche Scientifique, Quebec City, pp. 3-4.

Bergström, S.M., Saltzman, M.M. \& Schmitz, B. 2006: First record of the Hirnantian (Upper Ordovician) $813 \mathrm{C}$ excursion in the North American Midcontinent and its regional implications. Geological Magazine 143, 657-678.

https://doi.org/10.1017/S0016756806002469.

Bergström, S.M., Lehnert, O., Calner, M. \& Joachimski, M.M. 2012: A new upper Middle Ordovician-Lower Silurian drillcore standard succession from Borenshult in Östergötland, southern Sweden: 2. Significance of $\delta 13 \mathrm{C}$ chemostratigraphy. Geologiska Föreningen $i$ Stockholm Förhandlingar 134, 39-63. https://doi.org/10.1080/11035897.2012.657231.

Bergström, S.M., Eriksson, M.E., Young, S.A., Ahlberg, P. \& Schmitz, B. 2014: Hirnantian (latest Ordovician) $\delta 13 \mathrm{C}$ chemostratigraphy in southern Sweden and globally: a refined integration with the graptolite and conodont zone successions. Geologiska Föreningen $i$ Stockholm Förhandlingar 136, 355-386.

https://doi.org/10.1080/11035897.2013.851734.

Bockelie, J.F. 1984: The Diploporita of the Oslo Region, Norway. Palaeontology 27, 1-68.

Bockelie, J.F. 2013: Stop 23. Beach Section on Hovedøya (island in the Oslo Fiord). In Calner, M., Ahlberg, P., Lenert, O. \& Eldstrøm, M. (eds.): Field Guide for $3^{\text {rd }}$ Annual Meeting of the IGCP project 591, Rapporter och meddelanden, University of Lund 133, pp. 82-85.

Bockelie, J.F. \& Nystuen, J.P. 1985: The southeastern part of the Scandinavian Caledonides. In Gee, D.G. \& Sturt, B.A. (eds.): The Caledonide Orogen - Scandinavia and Related Areas, John Wiley, Chichester, pp. 69-68.

Bockelie, J.F. \& Rui, I. 2015: Geologisk kart over Vestmarka Lavaplatå i deler av Asker og Bærum, scale 1:10,000, ISBN 978-82-996355-2-3.

Braithwaite, C., Owen, A.W. \& Heath, R.A. 1995: Sedimentological change across the Ordovician-Silurian boundary in Hadeland and their implications for regional patterns of deposition in the Oslo Region. Norsk Geologisk Tidsskrift 75, 199-218.

Brenchley, P.J. \& Cocks, L.R.M. 1982: Ecological associations in a regressive sequence: The latest Ordovician of the Oslo-Asker District, Norway. Palaeontology 25, 783-815.

Brenchley, J.P. \& Cullen, B. 1982: The environmental distribution of associations belonging to the Hirnantia fauna-evidence from North Wales and Norway. In Bruton, D.L. (ed.): Aspects of the Ordovician System, Palaeontological Contributions from the University of Oslo No. 295, pp. 113-125.

Brenchley, P.J. \& Marshall, J.D. 1999: Relative timing of critical events during the late Ordovician mass extinction- new data from Oslo. Acta Universitatis Carolinae- Geologica 43, 187-190.

Brenchley, P.J. \& Newall, G. 1975: The stratigraphy of the Upper Ordovician Stage 5 in the Oslo-Asker District, Norway. Norsk Geologisk Tidsskrift 15, 243-275.

Brenchley, P.J. \& Newall, G. 1980: A facies analysis of Upper Ordovician regressive sequences in the Oslo Region, Norway-a record of glacioeustatic changes. Palaeogeography, Palaeoclimatology, Palaeoecology 31,1-38. https://doi.org/10.1016/0031-0182(80)90002-4.

Brenchley, J.P., Marshall, J.D., Hints, L. \& Nõlvak, J. 1997: New isotopic data solving and old biostratigraphic problem: the age of the Upper Ordovician brachiopod Holorhynchus giganteus. Journal of the Geological Society of London 154,335-342. https://doi.org/10.1144/gsigs.154.2.0335.

Brenchley, P.J., Marshall, J.D., Harper, D.A., Buttler, C.J. \& Underwood, C.J. 2006: A late Ordovician (Hirnantian) karstic surface in a submarine channel, recording glacio-eustatic sea-level changes: Meifod, central Wales. Geological Journal 41, 1-22. https://doi.org/10.1002/gj.1029.

Bruton, D.L., Gabrielsen, R.H. \& Larsen, B.T. 2010: The Caledonides of the Oslo Region, Norway-stratigraphy and structural elements. Norwegian Journal of Geology 90, 90-121.

Brøgger, W.C. 1887: Geologisk kart over øerne ved Kristiania. Nyt Magazin for Naturvidenskaberne 31, hefte 2, 1-31.

Cocks, L.R.M. 1982: The commoner brachiopods of the latest Ordovician of the Oslo-Asker district, Norway. Palaeontology 25, 755-781.

Davies, J.R., Waters, R.A., Williams, M., Wilson, D., Schofield, D.I. \& Zalasiewicz, J.A. 2009: Sedimentary and faunal events revealed by a revised correlation of post-glacial Hirnantian (Late Ordovician) strata in the Welsh Basin, UK. Geological Journal 44, 322-340. https://doi.org/10.1002/gj.1147.

Demski, M.W., Wheadon, B.J., Stewart, L.A., Elias, R.J., Young, G.A., Nowlan, G.S. \& Dobrzanski, E.P. 2015: Hirnantian strata identified in major intracratonic basins of central North America: implications for uppermost Ordovician stratigraphy. Canadian Journal of Earth Sciences 52, 68-76. https://doi.org/10.1139/cjes-2014-0156.

Franeck, F., Sandbakken, M.M., Midtkandal, I., Nakrem, H.A. \& Nystuen, J.P. 2015: A multi-phased incised valley system of the 
upper Ordovician in the Oslo Region. Norsk Geologisk Forening abstract and proceedings no 1, 31st Geological Winter Meeting of the Geological Society of Norway, 12-14 January, Stavanger, Norway, p. 31.

Ghienne, J.-F., Desrochers, A., Vandenbroucke, T.R.A., Achab, A., Asselin, E., Dabard, M.-P., Farley, C., Loi, A., Paris, F., Wickson, S. \& Veizer, J. 2014: A Cenozoic-style scenario for the end-Ordovician glaciation. Nature Communications 5, 1-9. https://doi.org/10.1038/ncomms5485.

Harper, D.A. \& Hints, L. 2016: Hirnantian (Late Ordovician) brachiopod faunas across Baltoscandia: A global and regional context. Palaeogeography, Palaeoclimatology, Palaeoecology 444, 71-83. https://doi.org/10.1016/j.palaeo.2015.11.044.

Harper, D.A., Hammarlund, E.U. \& Rasmussen, C.M. 2014: End Ordovician extinctions: a coincidence of causes. Gondwana Research 25, 1294-1307. https://doi.org/10.1016/j.gr.2012.12.021.

Hints, L., Pärnaste, H. \& Gailite, L.I. 2012: Hirnantia sagittifera (Brachiopoda) and Mucronaspis mucronata sl (Trilobita) in the Upper Ordovician of the East Baltic: taxonomy and distribution. Estonian Journal of Earth Sciences 61, 65-85. https://doi.org/10.3176/earth.2012.2.01.

Howe, M.P.A. 1982: The Lower Silurian graptolites of the Oslo Region. In Worsley, D. (ed.): Subcommission on Silurian stratigraphy. Field meeting in the Oslo Region 1982, Palaeontological Contributions from the University of Oslo, pp. 21-31.

Isaksen, D. 1982: En sedimentologisk og stratigrafisk undersøkelse av de over-Ordoviciske sedimentene på Spannslokket, Asker. Dissertation, University of Bergen, $201 \mathrm{pp}$.

Johnson, M.E. \& Baarli, B.G. 2007: Topography and depositional environments at the Ordovician-Silurian boundary in the IowaIllinois-Wisconsin region, USA. Acta Palaeontologica Sinica 46, 208-217.

Kaljo, D., Hints, L., Martma, T. \& Nõlvak, J. 2001: Carbon isotope stratigraphy in the latest Ordovician of Estonia. Chemical Geology 175, 49-59. https://doi.org/10.1016/S0009-2541(00)00363-6.

Kaljo, D., Martma, T., Neuman, B.E. \& Rønning, K. 2004: Carbon isotope dating of several uppermost Ordovician and lower Silurian sections in the Oslo Region, Norway. WOGOGOB-2004 8th Meeting on the Working Group on the Ordovician Geology of Baltoscandia, 13-18 May, Tallinn and Tartu, Estonia Organising Committee, p. 51.

Kiær, J. 1902: Etage 5 i Asker ved Kristiania. Norges geologiske undersøkelse 43, Aarbog 1902 no. 1, 1-112.

Kiær, J. 1908: Das Obersilur im Kristianiagebiete. Videnskabs-selskabets Skrifter I. Matematisk Naturvidenskapelig Klasse 1906 Bd. 2, 1-596.

Kjerulf, T. 1857: Über die Geologie des südlichen Norwegens. Nyt Magasin Naturvidenskap 9, 193-333.

Kröger, B., Ebbestad, J.O.R., Lehnert, O., Ullmann, C.V., Korte, C., Frei, R. \& Rasmussen, C.M. 2015: Subaerial speleothems and deep karst in central Sweden linked to Hirnantian glaciations. Journal of the Geological Society 172, 349-356. https://doi.org/10.1144/jgs2014-071.

Lervik, A. 1969: En stratigrafisk undersøkelse av etasje 5 i Barum. Thesis, University of Oslo, Norway, $91 \mathrm{pp}$.

Morley, C.K. 1986: Vertical strain variations in the Osen-Røa thrust sheet, North-western Oslo Fjord, Norway. Journal of Structural Geology 8, 621-632.

https://doi.org/10.1016/0191-8141(86)90068-4.

Naterstad, J., Bockelie, J.F., Bockelie, T., Graversen, O., Hjelmeland, H., Larsen, B.T. \& Nilsen, O. 1990: Asker 1814 I, berggrunnskart, scale 1:50,000, Norges geologiske undersøkelse.

Neuman, B. 1969: Upper Ordovician streptelasmatid corals from Scandinavia. Bulletin of the Geological Institution of the University of Uppsala N.S.1, 1-73.

Neuman, B. 1975: New Lower Palaeozoic streptelasmatid corals from Scandinavia. Norsk Geologisk Tidsskrift 55, 335-359.

Nordfjord, S., Goff, J.A., Austin, J.A. \& Gulick, S.P.S. 2006: Seismic facies of incised-valley fills, New Jersey continental shelf: implications for erosion and preservation processes acting during latest Pleistocene-Holocene transgression. Journal of Sedimentary Research 76, 1284-1303. https://doi.org/10.2110/jsr.2006.108.

Nystuen, J.P. 1981: The late Precambrian «sparagmites» of southern Norway: a major Caledonian allochthon - The Osen-Røa Nappe Complex. American Journal of Science 281, 69-94. https://doi.org/10.2475/ajs.281.1.69.

Owen, A., Bruton, D., Bockelie, J.F. \& Bockelie, T. 1990: The Ordovician succession of the Oslo Region, Norway. Norges geologiske undersøkelse Special Publication 4, 54 pp.

Sandbakken, M.M. 2014: Depositional History of Late Ordovicianearliest Silurian storm dominated shelf, incised valley and open marine settings, inner Oslofjorden islands (Oslo Region). MSc thesis, University of Oslo, $174 \mathrm{pp}$.

Seilacher, A. \& Meischner, D. 1964: Fazies-Analyse in Paläozoikum des Oslo-Gebietes. Geologischen Rundschau 54, 596-619. https://doi.org/10.1007/BF01820746.

Spjeldnæs, N. 1957: The Silurian/Ordovician Border in the Oslo District. Norsk Geologisk Tidsskrift 37, 355-371.

Stanistreet, I.G. 1978: Palaeoenvironments in the Upper Ordovician of the Oslo-Asker District, Norway. $\mathrm{PhD}$ thesis, University of Liverpool, Liverpool, PAGES pp.

Stanistreet, I.G. 1983: Contemporaneous faulting in the Upper Ordovician of the Oslo-Asker district, Norway, and its significance in the development of the Oslo Basin. Sedimentary Geology 37, 133-150. https://doi.org/10.1016/0037-0738(83)90074-X.

Stanistreet, I.G. 1989: Trace fossil associations related to facies of an upper Ordovician low wave energy shore face and shelf, Oslo-Asker district, Norway. Lethaia 22, 345-357. https://doi.org/10.1111/j.1502-3931.1989.tb01433.x.

Štorch, P. 2006: Facies development, depositional settings and sequence stratigraphy across the Ordovician-Silurian boundary: a new perspective from the Barrandian area of the Czech Republic. Geological Journal 41, 163-192. https://doi.org/10.1002/gj.1038.

Tonstad, K. 1983: En sedimentologisk og stratigrafisk undersøkelse av de over Ordoviciske sedimentene på Høyerholmen, Asker, Norge. Dissertation, University of Bergen, 246 pp.

Torsvik, T.H. \& Cocks, L.R.M. 2013: New global palaeogeographical reconstructions for the Early Palaeozoic and their generation. Geological Society of London Memoirs 38, 5-24. https://doi.org/10.1144/M38.2.

Wang, G., Zhan, R., Huang, B. \& Percival, I.G. 2016: Coral faunal turnover through the Ordovician-Silurian transition in South China and its global implications for carbonate stratigraphy and macroevolution. Geological Magazine 154, 829-836. https://doi.org/10.1017/S0016756816000741.

Worsley, D., Aarhus, N., Bassett, M.G., Howe, M.P.A., Mørk, A. \& Olaussen, S. 1983: The Silurian succession of the Oslo Region. Norges geologiske undersøkelse 384, 1-57.

Worsley, D., Baarli, B.G., Howe, M.P., Hjaltason, F. \& Alm, D. 2011: New data on the Bruflat Formation and the Llandovery/Wenlock transition in the Oslo Region, Norway. Norwegian Journal of Geology 91, 101-120. 